\title{
Trace gas and particle emissions from open biomass burning in Mexico
}

\author{
R. J. Yokelson ${ }^{1}$, I. R. Burling ${ }^{1}$, S. P. Urbanski ${ }^{2}$, E. L. Atlas ${ }^{3}$, K. Adachi ${ }^{4,5}$, P. R. Buseck ${ }^{4,5}$, C. Wiedinmyer ${ }^{6}$, \\ S. K. Akagi ${ }^{1}$, D. W. Toohey ${ }^{7}$, and C. E. Wold ${ }^{2}$ \\ ${ }^{1}$ University of Montana, Department of Chemistry, Missoula, MT, USA \\ ${ }^{2}$ USDA Forest Service, Fire Sciences Laboratory, Missoula, MT, USA \\ ${ }^{3}$ University of Miami, Rosenstiel School of Marine and Atmospheric Science, Miami, FL, USA \\ ${ }^{4}$ School of Earth and Space Exploration, Arizona State University, Tempe, AZ, USA \\ ${ }^{5}$ Department of Chemistry and Biochemistry, Arizona State University, Tempe, AZ, USA \\ ${ }^{6}$ National Center for Atmospheric Research, Boulder, CO, USA \\ ${ }^{7}$ University of Colorado, Department of Atmospheric and Oceanic Sciences, Boulder, CO, USA
}

Received: 23 January 2011 - Published in Atmos. Chem. Phys. Discuss.: 3 March 2011

Revised: 1 July 2011 - Accepted: 5 July 2011 - Published: 18 July 2011

\begin{abstract}
We report airborne measurements of emission factors $(\mathrm{EF})$ for trace gases and $\mathrm{PM}_{2.5}$ made in southern Mexico in March of 2006 on 6 crop residue fires, 3 tropical dry forest fires, 8 savanna fires, 1 garbage fire, and 7 mountain pine-oak forest fires. The savanna fire EF were measured early in the local dry season and when compared to EF measured late in the African dry season they were at least 1.7 times larger for $\mathrm{NO}_{\mathrm{x}}, \mathrm{NH}_{3}, \mathrm{H}_{2}$, and most non-methane organic compounds. Our measurements suggest that urban deposition and high windspeed may also be associated with significantly elevated $\mathrm{NO}_{\mathrm{x}} \mathrm{EF}$. When considering all fires sampled, the percentage of particles containing soot increased from 15 to $60 \%$ as the modified combustion efficiency increased from 0.88 to 0.98 . We estimate that about $175 \mathrm{Tg}$ of fuel was consumed by open burning of biomass and garbage and as biofuel (mainly wood cooking fires) in Mexico in 2006. Combining the fuel consumption estimates with our EF measurements suggests that the above combustion sources account for a large fraction of the reactive trace gases and more than $90 \%$ of the total primary, fine carbonaceous particles emitted by all combustion sources in Mexico.
\end{abstract}

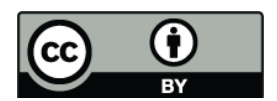

Correspondence to: R. J. Yokelson (bob.yokelson@umontana.edu)

\section{Introduction}

Biomass burning (BB) is the largest source of primary, fine carbonaceous particles and the second largest source of trace gases in the global atmosphere (Crutzen and Andreae, 1990; Bond et al., 2004). Industrial and domestic burning of biomass as a fuel (biofuel) occurs globally and year-round; roughly proportional to population, but with much higher use per capita in developing countries (Yevich and Logan, 2003). Open (outdoor) burning is even more widespread geographically, but it occurs mostly during the local dry season. The dry seasons of locations in the Southern Hemisphere (SH) tropics and the mid to high latitudes of the Northern Hemisphere (NH) can start as early as May-June and can last until October-November. The dry seasons in the NH tropics fall within the months of February-May; thus, large amounts of open burning emissions are being produced somewhere on Earth in nearly every month. Since most BB occurs in the SH tropics these fires have been studied the most (e.g. Sinha et al., 2003; Yokelson et al., 2008). Less is known about the emissions from the significant amounts of open BB that occur in the NH tropics (i.e. Mexico, Central America, northern South America, the Sahel region of Africa, India, and Indochina, van der Werf et al., 2010).

As part of the MILAGRO (Megacity Initiative Local and Global Research Observations) project (Fast et al., 2007; Molina et al., 2010), 56 open landscape-scale fires were sampled throughout southern and central Mexico from the air by a USFS Twin Otter and the NCAR C-130 in March of 2006

Published by Copernicus Publications on behalf of the European Geosciences Union. 
(Yokelson et al., 2007a, 2009). In addition, 22 fires were sampled from the ground in central Mexico during AprilMay of 2007 to characterize domestic and industrial biofuel burning (e.g. cooking fires, kilns, etc.), crop residue burning, and garbage burning (Christian et al., 2010). All these fires were sampled to meet a variety of objectives that includes: (1) determine the impact of the many different kinds of regional BB on the Mexico City Metropolitan Area (MCMA) and the BB contribution to the MCMA outflow, (2) better characterize the emissions from open and domestic BB in the $\mathrm{NH}$ tropics in general, and (3) learn more about the emissions from the significant amount of open biomass burning that occurs globally early in the dry season, but has been relatively undersampled (Hoffa et al., 1999; Korontzi et al., 2003).

Of the 56 fires sampled from the air, the airborne measurements of emission factors (EF) for 20 open fires in the Yucatan that were burning crop residue or tropical dry forest deforestation slash were described by Yokelson et al. (2009). That study also detailed measurements of the chemical evolution of one of the sampled plumes. An additional 8 fires sampled in the airborne work were understory fires in the urban-impacted, mountain pine-oak forests adjacent to the MCMA. These fires and their large impact on the MCMA outflow (accounting for roughly half the $\mathrm{PM}_{2.5}$ ) were described by Yokelson et al. (2007a) and Crounse et al. (2009). The emission factors from the 2007 ground-based fire sampling and a limited assessment of the impact of burning biofuel and garbage in the MCMA, Mexico, and the developing world in general were published by Christian et al. (2010).

The purpose of this paper is to present unpublished results for 25 additional open fires sampled from the Twin Otter during the 2006 airborne campaign and integrate these new data with the previously published results by fire type where applicable. The new airborne data include emission factors for 6 crop residue fires, 3 tropical dry forest fires, 8 savanna fires, 1 dump fire (open burning of garbage), and 7 fires in mountain pine-oak forests that were not impacted by urban emissions. Thus, this paper completes the presentation of the BB emission factor measurements made during MILAGRO. Coupled with the earlier papers, emission factors are now available for most of the major species emitted by many of the types of burning that are important within Mexico; a country with a high diversity of ecosystems and fire types. While most BB research has focused on savanna and forest fires, in fact, many different fire types are significant in most developing countries (Crutzen and Andreae, 1990; Akagi et al., 2011). In addition, by comparing the EF from these open fires to published EF for fires in similar ecosystems that burned during the late dry season, we find evidence for possible seasonal trends. We briefly describe the location and amounts of the different types of burning and the initial transport of the fire emissions. We conclude with an estimate of the combined impact of open burning and biofuel use in Mexico, which may be relevant to many developing nations.

\section{Experimental details}

The instruments deployed on the USFS Twin Otter and all of the data-handling procedures were described in detail by Yokelson et al. (2007a). A brief summary is presented next.

The University of Montana airborne Fourier transform infrared spectrometer (AFTIR) measured samples temporarily detained in the flow-through gas cell to quantify water vapor $\left(\mathrm{H}_{2} \mathrm{O}\right)$, carbon dioxide $\left(\mathrm{CO}_{2}\right)$, carbon monoxide $(\mathrm{CO})$, methane $\left(\mathrm{CH}_{4}\right)$, nitric oxide $(\mathrm{NO})$, nitrogen dioxide $\left(\mathrm{NO}_{2}\right)$, ammonia $\left(\mathrm{NH}_{3}\right)$, hydrogen cyanide $(\mathrm{HCN})$, ethene $\left(\mathrm{C}_{2} \mathrm{H}_{4}\right)$, ethyne $\left(\mathrm{C}_{2} \mathrm{H}_{2}\right)$, formaldehyde ( $\left.\mathrm{HCHO}\right)$, methanol $\left(\mathrm{CH}_{3} \mathrm{OH}\right)$, acetic acid $\left(\mathrm{CH}_{3} \mathrm{COOH}\right)$, formic acid $(\mathrm{HCOOH})$, and ozone $\left(\mathrm{O}_{3}\right)$. The $\mathrm{HCOOH}$ emission factors for the fires first presented in this work are based on the new measurement of the $\mathrm{HCOOH}$ infrared cross-section now adopted in the HITRAN database (Rothman et al., 2009). The HCOOH emission factors taken from previously published work were rescaled so that all the $\mathrm{HCOOH}$ emission factors herein stem from one consistent, updated analysis.

Ram air was grab-sampled into 2-1 stainless steel canisters for whole air sampling (WAS) and later analyzed at the University of Miami by gas chromatography (GC) with a flame ionization detector (FID) for $\mathrm{CH}_{4}$ and the following non-methane hydrocarbons (NMHC): ethane, $\mathrm{C}_{2} \mathrm{H}_{4}, \mathrm{C}_{2} \mathrm{H}_{2}$, propane, propene, isobutane, $\mathrm{n}$-butane, $\mathrm{t}$-2-butene, 1-butene, isobutene, c-2-butene, 1,3-butadiene, cyclopentane, isopentane, and n-pentane. $\mathrm{CO}$ was measured in parallel with the $\mathrm{CH}_{4}$ measurement, but utilized a GC with a Trace Analytical Reduction Gas Detector (RGD). Alternatively, at times, we collected 0.85 -L canisters for later analysis at the United States Forest Service (USFS) Fire Sciences Laboratory by GC/FID/RGD for $\mathrm{CO}_{2}, \mathrm{CO}, \mathrm{CH}_{4}, \mathrm{H}_{2}$, and several $\mathrm{C}_{2}-\mathrm{C}_{3}$ hydrocarbons. Details of the canister analysis are given by Weinheimer et al. (1998), Flocke et al. (1999), and Hao et al. (1996).

The canister-filling inlet (large diameter, fast flow) also supplied sample air for a Radiance Research Model 903 integrating nephelometer that measured "dry" (inlet $\mathrm{RH}<20 \%) b_{\text {scat }}$ at $530 \mathrm{~nm}$ at $0.5 \mathrm{~Hz}$. The $b_{\text {scat }}$ measured in inverse meters at the nephelometer temperature and pressure was converted to $b_{\text {scat }}$ at standard temperature and pressure (STP, $273 \mathrm{~K}, 1 \mathrm{~atm}$ ) and then multiplied by $208800 \pm 11900 \mu \mathrm{g} \mathrm{s} \mathrm{m}^{-2}$ to yield the mass of particles with aerodynamic diameter $<2.5$ microns $\left(\mathrm{PM}_{2.5}\right)$ in $\mu \mathrm{g} \mathrm{s} \mathrm{m}^{-3}$ of air, based on a gravimetric "calibration" similar to that described by Trent et al. (2000). Our conversion factor is equivalent to a mass scattering efficiency (MSE) of $4.8 \mathrm{~s} \mathrm{~m}^{2} \mathrm{~g}^{-1}$. The MSE obtained in airborne studies of fresh smoke from other fuel types (e.g. Nance et al., 1993) differ by up to $\sim 20 \%$, which we take as a rough estimate of the uncertainty in our $\mathrm{PM}_{2.5}$ values.

An isokinetic particle inlet sampled fine particles with a diameter cut-off of a few microns. Particles of diameter $<1$ micron account for nearly all the fine particle $\left(\mathrm{PM}_{2.5}\right)$ mass 
emitted by biomass fires (Reid et al., 2005). This inlet supplied sample air to two particle impactor samplers (MPS3, California Measurements, Inc.) that were used to collect aerosol particles having aerodynamic diameters between 0.05 and 0.3 microns onto lacey-carbon transmission electron microscope (TEM) grids. Sampling times in fire plumes were $<1 \mathrm{~min}$. Three TEMs were used for subsequent imaging and compositional analyses of these aerosol particles: a Tecnai F20 (FEI Corp.), a CM 200 (Philips Corp.), and a 2010F (JEOL) (Adachi and Buseck, 2008, 2010). They were operated at an accelerating voltage of $200 \mathrm{kV}$. Detailed sampling and analysis conditions are described by Adachi and Buseck (2008). The isokinetic particle inlet also supplied a LiCor (Model \# 7000) measuring $\mathrm{CO}_{2}$ and $\mathrm{H}_{2} \mathrm{O}$ at $5 \mathrm{~Hz}$ and a UHSAS (Ultra High Sensitivity Aerosol Spectrometer, Particle Metrics, Inc.) deployed by the University of Colorado. The UHSAS provided the number of particles in each of 99 user-selectable bins for diameters between 55 and $1000 \mathrm{~nm}$ at $1 \mathrm{~Hz}$. All three Twin Otter inlets were located within $30 \mathrm{~cm}$ of each other. The nephelometer was not available on the 12 March flight so we used the UHSAS particle counting/size data to indirectly determine particle mass. As in previous studies (Yokelson et al., 2007a, 2009), we assumed all particles to be spheres with diameters determined from a Mie scattering response curve generated with polystyrene latex spheres. These results are not corrected for assumed differences in index of refraction, which could undersize the particles by $6 \%$ or more in diameter for indices of refraction less than 1.5. The UHSAS only detects high albedo particles (e.g., black carbon is undersampled and, for this study, can be assumed to go largely undetected by the UHSAS). We integrated the UHSAS size distributions to obtain an estimate of the volume of particles $\left(\mathrm{PV}_{1}, \mu \mathrm{m}^{3} \mathrm{~cm}^{-3}\right)$ in air at $1 \mathrm{~Hz}$ and found that the $\mathrm{PV}_{1}$ (for $\mathrm{PV}_{1}<\sim 30$ ) was related to $b_{\text {scat }}$ measured by the nephelometer as follows:

$b_{\text {scat }}=\mathrm{PV}_{1} \times 1.25( \pm 0.25) \times 10^{-5}$

On 12 March, the $\mathrm{PV}_{1}$ did not exceed $30 \mu \mathrm{m}^{3} \mathrm{~cm}^{-3}$ in the plume of Fire \#3. We used Equation 1 to convert $\mathrm{PV}_{1}$ to $b_{\text {scat }}$ and then converted $b_{\text {scat }}$ to $\mathrm{PM}_{2.5}$ as described above. The resulting $\mathrm{PM}_{2.5}$ value has an estimated uncertainty of about $32 \%$.

\subsection{Generalized airborne sampling protocol}

The Twin Otter was based in Veracruz with the other MILAGRO research aircraft (http://mirage-mex.acd.ucar.edu/). The main goal of the Twin Otter flights was to sample fires throughout south-central Mexico. Background air (i.e. ambient boundary layer air not in plumes) was characterized when not sampling BB plumes. The continuous instruments operated in real time in background air. The grab sampling instruments acquired numerous spot measurements that were representative of the background air since the continuous instruments showed that the background air was well-mixed on the spatial scale corresponding to the discrete sampling intervals.

To measure the initial emissions from the fires, the aircraft sampled smoke less than several minutes old by penetrating the column of smoke, up to six times per fire, at $150-600 \mathrm{~m}$ above the active flame front as terrain allowed. The continuous instruments monitored their species while penetrating the plume. The AFTIR, MPS-3, and WAS were used for spot measurements in the smoke plumes. For every grab sample of the smoke plume we also collected a paired, local, background grab sample just outside the plume. These paired samples allow calculation of the most accurate excess mixing ratios for the smoke (see next section).

\subsection{Data processing and synthesis}

Grab samples of both the plume and the adjacent background were used to calculate excess mixing ratios $(\Delta \mathrm{X}$, the mixing ratio of species " $X$ " in the plume minus the mixing ratio of " $\mathrm{X}$ " in the background air). $\Delta \mathrm{X}$ reflects the degree of dilution of the plume and the instrument response time. Thus, a useful, derived quantity is the normalized excess mixing ratio (NEMR) where $\Delta \mathrm{X}$ is divided by the "simultaneously" measured excess mixing ratio of another species $(\Delta \mathrm{Y})$; usually a fairly long-lived plume "tracer" such as $\Delta \mathrm{CO}$ or $\Delta \mathrm{CO}_{2}$. A measurement of $\Delta \mathrm{X} / \Delta \mathrm{Y}$ in a plume up to a few minutes old is a molar emission ratio (ER). We computed fire-average molar ER for each individual fire from grab or discrete samples as follows. First, if there is only one sample of a fire then the calculation is trivial and equivalent to the definition of $\Delta X / \Delta Y$ given above. For multiple grab samples of a fire, the fire-average ER was obtained from the slope of the least-squares line (with the intercept forced to zero) in a plot of one set of excess mixing ratios versus another. This method is justified in detail by Yokelson et al. (1999). When the AFTIR and WAS measured the same pair of compounds on the same fire, their data were combined in the plots as shown in Fig. 1a of Yokelson et al. (2009). The CO and $\mathrm{CO}_{2}$ data from AFTIR and WAS were also used to calculate fire-average modified combustion efficiencies (MCE). MCE is defined as $\Delta \mathrm{CO}_{2} /\left(\Delta \mathrm{CO}_{2}+\Delta \mathrm{CO}\right)$ and is also equal to $1 /\left(1+\left(\Delta \mathrm{CO} / \Delta \mathrm{CO}_{2}\right)\right)$. We use fire-average MCE in Sect. 3 as an index of the relative amount of fuel consumption by flaming and smoldering combustion, with high MCE indicating a fire with relatively more flaming (Akagi et al., 2011).

A few of the grab-sample based ER were from measurements that were not made on the same instrument. The molar ER to $\mathrm{CO}_{2}$ for each NMHC measured by U-Miami WAS on the Twin Otter was derived for each fire as follows. The molar ER to CO measured by WAS from a fire was multiplied by the molar $\triangle \mathrm{CO} / \Delta \mathrm{CO}_{2}$ ER measured on that same fire by AFTIR. CO was measured with high accuracy by AFTIR and WAS. This facilitated coupling data from the two methods.

Emission ratios were obtained from the continuous instruments by comparing the integrals of $\Delta \mathrm{X}$ and $\Delta \mathrm{Y}$ as the 


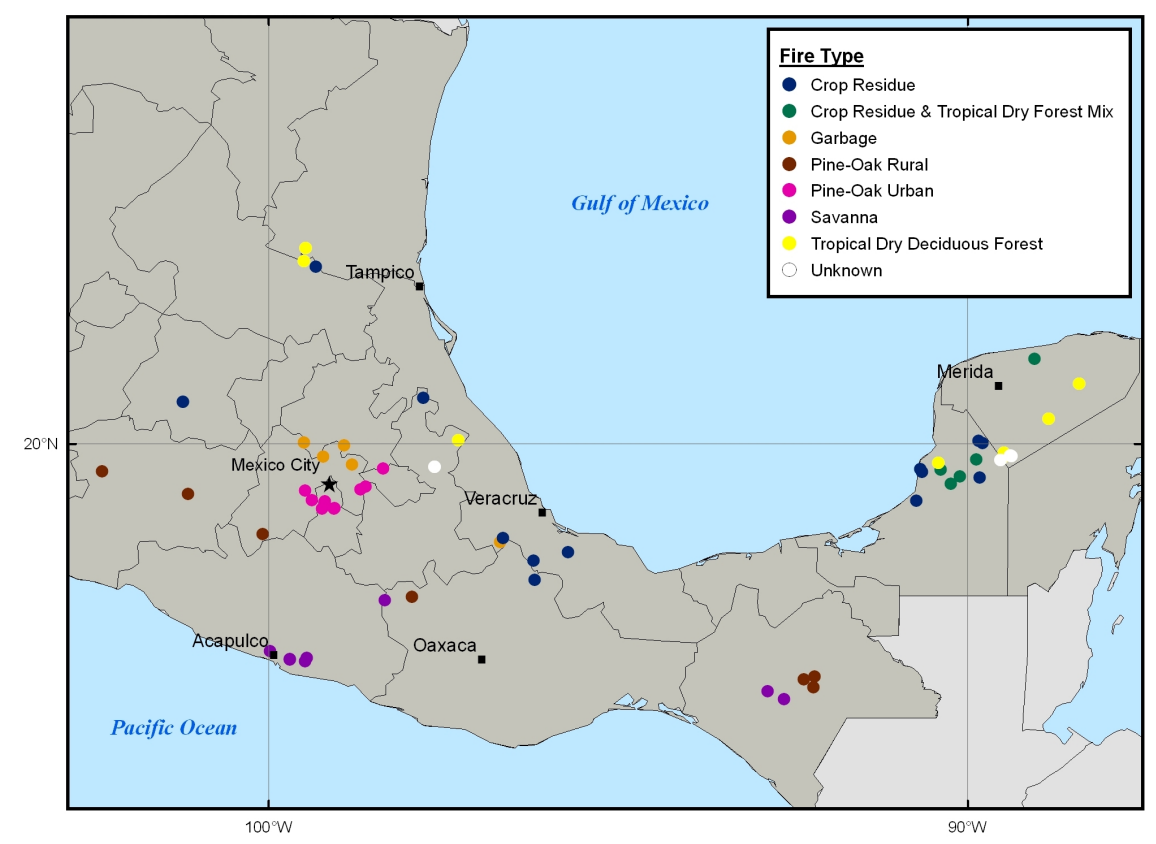

Fig. 1. Map showing location of open biomass burning sampled in Mexico in 2006 and 2007.

aircraft passed through a nascent smoke plume (e.g. $\mathrm{PM}_{2.5}$ from nephelometer and $\mathrm{LiCor} \mathrm{CO}_{2}$ ). While the instantaneous $\Delta \mathrm{X} / \Delta \mathrm{Y}$ would be affected by any difference in "realtime" instrument response times, comparing the integrals compensates for this (Karl et al., 2007). When only one pass was made through the plume of a fire, the ratio of the integrals was taken as the ER. When more than one pass was made through the plume of a single fire, we plotted the integrals versus each other and obtained the ER from the slope; analogous to the grab sample plots. Figure 1 in Yokelson et al. (2009) illustrates the typical analyte levels we encountered and gives examples of ER derivations.

\subsection{Estimation of fire-average emission factors}

For any carbonaceous fuel, a set of ER to $\mathrm{CO}_{2}$ for the other major carbon emissions (i.e. $\mathrm{CO}, \mathrm{CH}_{4}$, a suite of nonmethane organic compounds (NMOC), particle carbon, etc.) can be used to calculate emission factors (EF, g compound emitted per kg dry fuel burned) for all the emissions quantified from the source using the carbon mass-balance method (Yokelson et al., 1999). The carbon mass balance method assumes that all the carbon released to the atmosphere is detected. We approximated total carbon emissions for our EF calculation from AFTIR measurements of $\mathrm{CO}_{2}, \mathrm{CO}, \mathrm{CH}_{4}$, and NMOC and WAS measurements of $\mathrm{CO}_{2}, \mathrm{CO}, \mathrm{CH}_{4}$, and non-methane hydrocarbons (NMHC, a subset of NMOC consisting of compounds containing only $\mathrm{C}$ and $\mathrm{H}$ and not $\mathrm{O}$, $\mathrm{N}$, etc.). The nephelometer $\mathrm{PM}_{2.5}$ and measurements made on the C-130 during MILAGRO of the mass fraction of $\mathrm{C}$ in BB aerosol (0.48-0.68; Yokelson et al., 2009) were used to estimate the particulate carbon. By ignoring unmeasured gases, we may overestimate the emission factors by $1-2 \%$ (Andreae and Merlet, 2001; Akagi et al., 2011). We assumed that all the vegetation fires burned in fuels that were $50 \% \mathrm{C}$ by mass on a dry weight basis (Susott et al., 1996), but the actual fuel carbon percentage could vary by $\pm 10 \%(2 \sigma)$ of our nominal value. EF scale linearly with the assumed fuel carbon fraction. Because much of the NO is quickly converted to $\mathrm{NO}_{2}$ after emission, we also report an $\mathrm{EF}$ for " $\mathrm{NO}_{\mathrm{x}}$ as NO." For any species "X" we abbreviate the EF as EFX. Because the sensitivity of the instruments varies by species and the degree of smoke dilution varied by fire, when an EF is not reported it should not be assumed to have a low value.

\subsection{Details of flights}

For the 28 fires sampled from the air on $6,9,12,17,18$, 22, 23, and 29 of March 2006; the flight paths, fire locations, sampling times, MODIS active fire ("hotspot") detection rate, flight narrative, and other details were included in previous papers (Yokelson et al., 2007a, 2009). The airborne data first presented in this work were gathered on 4, 8, 11, 20, 25, 27, and 28 March 2006 during flight missions to the Mexican states of Veracruz, Veracruz and Puebla, Tamaulipas and San Luis Potosi, Chiapas, Oaxaca, Guerrero and Mexico, and Michoacán, respectively. The fire locations for these dates and all the other Mexican airborne fire sampling are shown in Fig. 1 along with the six open fires sampled from the ground. Table 1 presents the fire date, identifying number, location, sampling time, hot spot detection information, and a simple fuel description for all the March 2006 airborne fire sampling 
Table 1. Details of the open fires (not including biofuels) sampled in Mexico during MILAGRO.

\begin{tabular}{|c|c|c|c|c|c|c|c|c|c|c|}
\hline \multirow{2}{*}{$\begin{array}{l}\text { Date } \\
\mathrm{dd} / \mathrm{mm} / \mathrm{yy}\end{array}$} & \multirow{2}{*}{$\begin{array}{r}\text { Fire } \\
\#\end{array}$} & \multirow{2}{*}{\multicolumn{2}{|c|}{$\begin{array}{l}\text { Lat Long } \\
\text { decimal degrees }\end{array}$}} & \multirow{2}{*}{$\begin{array}{r}\text { Time } \\
\text { LT }\end{array}$} & \multicolumn{2}{|c|}{ MODIS Overpass $^{1}$} & \multirow{2}{*}{$\begin{array}{r}\text { Hotspot } \\
\mathrm{Y} / \mathrm{N}\end{array}$} & \multirow[t]{2}{*}{ Platform } & \multirow{2}{*}{$\begin{array}{l}\text { Fuels } \\
\text { observed from aircraft or ground }\end{array}$} & \multirow[b]{2}{*}{$\operatorname{Ref}^{2}$} \\
\hline & & & & & Terra LT & Aqua LT & & & & \\
\hline \multicolumn{11}{|c|}{ Fires sampled from the air in March of 2006} \\
\hline $04 / 03 / 06$ & 1 & 18.3209 & -96.2067 & 1454 & 1125 & - & $\mathrm{N}$ & Twin Otter & Crop Residue & \\
\hline $04 / 03 / 06$ & 2 & 18.0509 & -96.1922 & 1511 & 1125 & - & $\mathrm{N}$ & Twin Otter & Crop Residue & \\
\hline 04/03/06 & 3 & 18.4408 & -95.7162 & 1542 & 1125 & - & $\mathrm{N}$ & Twin Otter & Crop Residue & \\
\hline 06/03/06 & 1 & 19.0763 & -99.0537 & 1327 & 1115 & 1420 & $\mathrm{~N}$ & Twin Otter & Pine-Oak Urban & 1 \\
\hline 06/03/06 & 2 & 19.1739 & -99.1903 & 1332 & 1115 & 1420 & $\mathrm{~N}$ & Twin Otter & Pine-Oak Urban & 1 \\
\hline 06/03/06 & 3 & 19.1881 & -99.3783 & $1705-1709$ & 1115 & 1420 & $\mathrm{~N}$ & Twin Otter & Pine-Oak Urban & 1 \\
\hline 06/03/06 & 4 & 19.0711 & -99.2283 & 1714 & 1115 & 1420 & $\mathrm{~N}$ & Twin Otter & Pine-Oak Urban & 1 \\
\hline 08/03/06 & 1 & 20.6510 & -97.7880 & $1621-1624$ & 1100 & 1405 & $\mathrm{~N}$ & Twin Otter & Crop Residue & \\
\hline 08/03/06 & 2 & 20.0480 & -97.2830 & 1646 & 1100 & 1405 & $\mathrm{Y}$ & Twin Otter & Tropical Dry Deciduous Forest & \\
\hline 09/03/06 & 1 & 19.3269 & -99.4775 & 1320 & - & - & $\mathrm{N}$ & Twin Otter & Pine-Oak Urban & 1 \\
\hline $10 / 03 / 06$ & 1 & 19.6431 & -98.3578 & 1716 & 1050 & 1355 & $\mathrm{~N}$ & $\mathrm{C}-130$ & Pine-Oak Urban & 1 \\
\hline $11 / 03 / 06$ & 1 & 22.5314 & -99.3219 & $1444-1455$ & 1130 & - & $\mathrm{Y}$ & Twin Otter & Crop Residue & \\
\hline $11 / 03 / 06$ & 2 & 22.6132 & -99.4895 & $1502-1512$ & 1130 & - & $\mathrm{N}$ & Twin Otter & Tropical Dry Deciduous Forest & \\
\hline $11 / 03 / 06$ & 3 & 22.7939 & -99.4674 & $1523-1525$ & 1130 & - & $\mathrm{N}$ & Twin Otter & Tropical Dry Deciduous Forest & \\
\hline $12 / 03 / 06$ & 3 & 19.1834 & -90.7269 & $1405-1409$ & 1035 & - & Y & Twin Otter & Crop Residue & 2 \\
\hline $12 / 03 / 06$ & 4 & 19.6330 & -90.6758 & $1420-1424$ & 1035 & - & $\mathrm{N}$ & Twin Otter & Crop Residue & 2 \\
\hline $12 / 03 / 06$ & 5 & 19.5947 & -90.6497 & 1555 & 1035 & - & $\mathrm{N}$ & Twin Otter & Crop Residue & 2 \\
\hline $17 / 03 / 06$ & 1 & 19.0681 & -99.0616 & $1158-1242$ & 1055 & 1400 & $\mathrm{~N}$ & Twin Otter & Pine-Oak Urban & 1 \\
\hline $17 / 03 / 06$ & 2 & 19.3862 & -98.6066 & $1306-1318$ & 1055 & 1400 & $\mathrm{~N}$ & Twin Otter & Pine-Oak Urban & 1 \\
\hline $18 / 03 / 06$ & 1 & 19.6685 & -97.6232 & $1452-1511$ & 1140 & - & $\mathrm{N}$ & Twin Otter & Unknown & \\
\hline $18 / 03 / 06$ & 2 & 19.3456 & -98.6851 & $1546-1639$ & 1140 & - & $\mathrm{N}$ & Twin Otter & Pine-Oak Urban & 1 \\
\hline $18 / 03 / 06$ & 3 & 19.4906 & -98.0558 & $1709-1715$ & 1140 & - & $\mathrm{N}$ & Twin Otter & Pinyon Pine and Juniper & \\
\hline 20/03/06 & 1 & 16.6613 & -92.1847 & $1248-1300$ & 1125 & 1250 & $\mathrm{~N}$ & Twin Otter & Pine-Oak Rural & \\
\hline 20/03/06 & 2 & 16.6225 & -92.3365 & $1305-1307$ & 1125 & 1250 & $\mathrm{~N}$ & Twin Otter & Pine-Oak Rural & \\
\hline 20/03/06 & 3 & 16.5068 & -92.1999 & 1314-1339 & 1125 & 1250 & $\mathrm{Y}$ & Twin Otter & Pine-Oak Rural & \\
\hline 20/03/06 & 4 & 16.3384 & -92.6197 & $1343-1349$ & 1125 & 1250 & $\mathrm{~N}$ & Twin Otter & Savanna & \\
\hline 20/03/06 & 5 & 16.4534 & -92.8539 & $1402-1409$ & 1125 & 1250 & $\mathrm{Y}$ & Twin Otter & Savanna & \\
\hline 22/03/06 & 1 & 19.5306 & -90.1063 & $1314-1317$ & 1115 & 1240 & $\mathrm{~N}$ & Twin Otter & Crop Residue \& Tropical Dry Forest Mix & 2 \\
\hline 22/03/06 & 2 & 19.7748 & -89.8675 & $1329-1333$ & 1115 & 1240 & $\mathrm{Y}$ & Twin Otter & Crop Residue \& Tropical Dry Forest Mix & 2 \\
\hline 22/03/06 & 3 & 19.7703 & -89.5177 & $1344-1348$ & 1115 & 1240 & $\mathrm{~N}$ & Twin Otter & Tropical Dry Deciduous Forest & 2 \\
\hline 22/03/06 & 4 & 19.8158 & -89.4578 & $1353-1356$ & 1115 & 1240 & $\mathrm{~N}$ & Twin Otter & Tropical Dry Deciduous Forest & 2 \\
\hline 22/03/06 & 5 & 19.8649 & -89.4717 & $1358-1401$ & 1115 & 1240 & $\mathrm{~N}$ & Twin Otter & Tropical Dry Deciduous Forest & 2 \\
\hline 22/03/06 & 6 & 20.3532 & -88.8383 & $1424-1427$ & 1115 & 1240 & $\mathrm{~N}$ & Twin Otter & Tropical Dry Deciduous Forest & 2 \\
\hline $22 / 03 / 06$ & 7 & 20.8525 & -88.4018 & $1447-1450$ & 1115 & 1240 & $\mathrm{~N}$ & Twin Otter & Tropical Dry Deciduous Forest & 2 \\
\hline 22/03/06 & 8 & 21.2085 & -89.0345 & $1512-1529$ & 1115 & 1240 & $\mathrm{Y}$ & Twin Otter & Crop Residue \& Tropical Dry Forest Mix & 2 \\
\hline 23/03/06 & 1 & 19.8266 & -89.3825 & 1410 & 1020 & 1325 & $\mathrm{~N}$ & C- 130 & Unknown & 2 \\
\hline $23 / 03 / 06$ & 2 & 19.7648 & -89.5220 & 1412 & 1020 & 1325 & Y & C- 130 & Unknown & 2 \\
\hline 23/03/06 & 3 & 19.8201 & -89.3681 & 1417 & 1020 & 1325 & $\mathrm{~N}$ & C-130 & Unknown & 2 \\
\hline 25/03/06 & 1 & 17.8018 & -97.9430 & $1304-1317$ & - & - & $\mathrm{N}$ & Twin Otter & Pine-Oak Rural & \\
\hline $25 / 03 / 06$ & 2 & 18.5907 & -96.6805 & $1428-1432$ & - & - & $\mathrm{N}$ & Twin Otter & Garbage & \\
\hline 25/03/06 & 3 & 18.6488 & -96.6410 & 1435 & - & - & $\mathrm{N}$ & Twin Otter & Crop Residue & \\
\hline 27/03/06 & 1 & 18.7020 & -100.0799 & $1246-1254$ & 1130 & - & $\mathrm{N}$ & Twin Otter & Pine-Oak Rural & \\
\hline $27 / 03 / 06$ & 2 & 17.0270 & -99.9755 & $1353-1354$ & 1130 & - & $\mathrm{N}$ & Twin Otter & Savanna & \\
\hline 27/03/06 & 3 & 16.9111 & -99.6913 & $1404-1407$ & 1130 & - & $\mathrm{N}$ & Twin Otter & Savanna & \\
\hline 27/03/06 & 4 & 16.9302 & -99.4475 & $1414-1422$ & 1130 & - & $\mathrm{N}$ & Twin Otter & Savanna & \\
\hline $27 / 03 / 06$ & 5 & 16.8788 & -99.4733 & $1427-1428$ & 1130 & - & $\mathrm{N}$ & Twin Otter & Savanna & \\
\hline 27/03/06 & 6 & 16.9103 & -99.6917 & $1433-1439$ & 1130 & - & $\mathrm{N}$ & Twin Otter & Savanna & \\
\hline 27/03/06 & 7 & 17.7585 & -98.3360 & $1638-1642$ & 1130 & - & $\mathrm{N}$ & Twin Otter & Savanna & \\
\hline 28/03/06 & 1 & 19.2787 & -101.1498 & $1141-1145$ & - & 1340 & $\mathrm{Y}$ & Twin Otter & Pine-Oak Rural & \\
\hline 28/03/06 & 2 & 19.6021 & -102.3766 & $1415-1423$ & - & 1340 & $\mathrm{~N}$ & Twin Otter & Pine-Oak Rural & \\
\hline 29/03/06 & 1 & 19.6235 & -90.3815 & $1337-1353$ & 1120 & 1245 & $\mathrm{Y}$ & Twin Otter & Crop Residue \& Tropical Dry Forest Mix & 2 \\
\hline 29/03/06 & 2 & 19.7208 & -90.4108 & 1346 & 1120 & 1245 & $\mathrm{~N}$ & Twin Otter & Tropical Dry Deciduous Forest & 2 \\
\hline 29/03/06 & 3 & 19.4230 & -90.2315 & 1400 & 1120 & 1245 & $\mathrm{~N}$ & Twin Otter & Crop Residue \& Tropical Dry Forest Mix & 2 \\
\hline 29/03/06 & 4 & 19.5128 & -89.8192 & $1412-1416$ & 1120 & 1245 & $\mathrm{~N}$ & Twin Otter & Crop Residue & 2 \\
\hline 29/03/06 & 5 & 20.0371 & -89.8395 & $1435-1448$ & 1120 & 1245 & $\mathrm{~N}$ & Twin Otter & Crop Residue & 2 \\
\hline 29/03/06 & 6 & 20.0055 & -89.7808 & $1438-1441$ & 1120 & 1245 & $\mathrm{~N}$ & Twin Otter & Crop Residue & 2 \\
\hline \multicolumn{11}{|c|}{ Fires sampled from the ground in 2007} \\
\hline 23/04/07 & 1 & 20.01 & -99.49 & $1648-1748$ & - & - & - & Ground & Garbage & 3 \\
\hline $24 / 04 / 07$ & 1 & 19.81 & -99.22 & $1304-1841$ & - & - & - & Ground & Garbage & 3 \\
\hline $25 / 04 / 07$ & 1 & 19.97 & -98.92 & $1355-1502$ & - & - & - & Ground & Garbage & 3 \\
\hline 26/04/07 & 1 & 19.70 & -98.80 & $1321-1438$ & - & - & - & Ground & Garbage & 3 \\
\hline $30 / 04 / 07$ & 1 & 20.60 & -101.22 & $1246-1334$ & - & - & - & Ground & Crop Residue & 3 \\
\hline $01 / 05 / 07$ & 1 & 20.60 & -101.22 & $1426-1518$ & - & - & - & Ground & Crop Residue & 3 \\
\hline
\end{tabular}

\footnotetext{
${ }^{1}$ Blank entries indicate the MODIS scene was heavily impacted by clouds or that the sampled fire(s) were located on the extreme edge of the scene or outside of the scene.
}

${ }^{2}$ Yokelson et al. $(2007 \mathrm{a})=1$, Yokelson et al. $(2009)=2$, Christian et al. $(2010)=3$. No number is assigned to fires for which EF data is first published in this work. 
in Mexico. Also shown in Table 1 is basic information for the 6 open fires sampled from the ground during the spring of 2007 (4 garbage burning and 2 crop residue) with more details available in Christian et al. (2010).

\section{Results and discussion}

We begin this section by noting two issues that affect the discussion of the emissions from all the fire types addressed in this study (1) the terminology for light-absorbing carbon, and (2) the calculation of average emission factors for a fire type. In this paper we recognize three different methods of estimating the amount of $\mathrm{sp}^{2}$-bonded carbon clusters in the particles, which are responsible for most of the aerosol visible light absorption. Black carbon (BC) emission factors are based on direct optical absorption measurements combined with a mass absorption efficiency or calibrated incandescence measurements. Elemental carbon emission factors are based on thermo-optical, gravimetric measurements that isolate the mass of $\mathrm{sp}^{2}$-hybridized carbon. Soot is identified by its fractal shape and $\mathrm{sp}^{2}$-carbon bond peak in the electron energy-loss spectra (EELS) in the TEM and is believed to account for most, if not all, black carbon. In our discussion we assume that the $\mathrm{EF}$ for $\mathrm{EC}$ and $\mathrm{BC}$ are approximately equivalent, although this is not always strictly the case. We also use the number fraction of soot particles as a qualitative estimate of the aerosol's tendency to absorb visible light and thereby impact radiative forcing. Detailed discussion of these techniques can be found elsewhere (Reid et al., 2005; Bond and Bergstrom, 2006; Moteki and Kondo, 2007). We also use a new procedure for calculating the average emission factors for each vegetation fire type in this paper. The rationale for this new method and the details of its implementation are developed in case study format in Sect. 3.1.1.

\subsection{Emission factors for types of open burning common in Mexico}

\subsubsection{Crop residue fires and description of a new method for deriving average emission factors}

Table 2 shows all the trace gas EF measured for crop residue (CR) fires in Mexico as part of MILAGRO. It includes EF for 6 CR fires measured from the air during March 2006 in the Yucatan published in Yokelson et al. (2009) and EF for 2 $\mathrm{CR}$ fires measured from the ground in central Mexico during spring 2007 published in Christian et al. (2010). Table 2 also includes previously unpublished EF for $6 \mathrm{CR}$ fires measured from the air during March 2006 throughout south/central Mexico as shown in Table 1. We were not able to identify the specific type of crop associated with these fires from the air, but all the CR fires reported in Table 2 were of the type where loosely-packed residue burned mostly by flaming combustion in the field. This is typical of mechanized agriculture and contrasts with much of the crop residue burning in eastern Asia where piles of hand-processed residue burn mostly by smoldering (Christian et al., 2003).

The data in Table 2 can be used to calculate a straight average and standard deviation for the newly-presented CR fires or the Yucatan CR fires separately, with the latter already shown in Yokelson et al. (2009). We found that these average values for the two groups of CR fires were qualitatively similar for all species except acetic acid. Thus, in Table 2 we compute "national average" EF for all the crop residue fires in Mexico. These values apply to a larger geographic region and are based on a larger sample size.

We use two different methods to compute the average values as discussed in detail next. The average fire-integrated MCE is an important parameter to estimate accurately because it reflects the "typical" flaming to smoldering ratio, which has a major influence on nearly all the EF. We make the assumption that our estimate of the average MCE will be more representative if the sample size is larger. Thus, since we measured $\mathrm{CO}_{2}$ and $\mathrm{CO}$ in every fire plume, we take the average MCE for all the CR fires we sampled as our best estimate of the average MCE for all Mexican CR fires. We recognize that our samples are biased temporally (early dry season), geographically (Yucatan and south-central Mexico), and methodologically (12 air versus 2 ground where the latter tends to observe lower MCE). On the other hand we have no valid basis for improving our estimate by excluding certain fires. Thus, we conclude that the average MCE of all our CR fires currently represents our best estimate of the average mix of flaming and smoldering combustion associated with Mexican CR fires.

Because of the strong EF dependence on MCE we need to derive average $\mathrm{EF}$ that are consistent with the average MCE based on all the fires. However, for various technical reasons (see Sect. 2), we did not acquire data for every species on every fire. The situation is illustrated in Fig. 2 using 1,3-butadiene, which was measured on only 6 of the 14 $\mathrm{CR}$ fires, as an example. For the six fires with 1,3-butadiene data the average $\mathrm{EF}$ was $0.114 \mathrm{~g} \mathrm{~kg}^{-1}$ (open square in Fig. 2) and the average MCE was 0.940. Thus the straight average $\mathrm{EF}$ is appropriate for an MCE of 0.940 rather than the average MCE of 0.925 for all CR fires. To derive an EF that is consistent with the average CR fire MCE, we fit a regression line to EF versus MCE using the 6 available measurements and then use the regression equation to calculate an $\mathrm{EF}$ at the average MCE for CR fires. This procedure yields an $\mathrm{EF}$ of $0.151 \mathrm{~g} \mathrm{~kg}^{-1}$ (filled square Fig. 2), which is consistent with the more extensive MCE information. Thus, for all the species other than $\mathrm{CO}$ and $\mathrm{CO}_{2}$, we plotted the available EFs versus $\mathrm{MCE}$, fit a regression line to those data, and then computed a recommended EF from the fit at the average MCE for all the CR fires (shown in the last column of Table 2). This procedure gives the "straight average" EF when the species was measured on all the fires and an EF that is consistent with the average MCE when a species was measured only on 
Table 2. Emission factors (EF, $\mathrm{g} \mathrm{kg}^{-1}$ ) and modified combustion efficiency (MCE) measured for crop residue fires.

\begin{tabular}{|c|c|c|c|c|c|c|c|c|c|c|c|c|c|c|c|c|c|}
\hline Date & $4 / 3 / 06$ & $4 / 3 / 06$ & $4 / 3 / 06$ & $8 / 3 / 06$ & $11 / 3 / 06$ & $25 / 3 / 06$ & $12 / 3 / 06$ & $12 / 3 / 06$ & $12 / 3 / 06$ & $29 / 3 / 06$ & $29 / 3 / 06$ & $29 / 3 / 06$ & $30 / 4 / 07$ & $1 / 5 / 07$ & Average & Stdev & $\mathrm{EF}$ at \\
\hline Fire \# & 1 & 2 & 3 & 1 & 1 & 3 & 3 & 4 & 5 & 4 & 5 & 6 & 1 & 1 & & & average \\
\hline MCE & 0.970 & 0.945 & 0.870 & 0.911 & 0.908 & 0.950 & 0.928 & 0.950 & 0.956 & 0.892 & 0.941 & 0.937 & 0.910 & 0.882 & 0.925 & 0.030 & MCE \\
\hline Species & $\mathrm{EF}$ & $\mathrm{EF}$ & EF & EF & $\mathrm{EF}$ & $\mathrm{EF}$ & $\mathrm{EF}$ & $\mathrm{EF}$ & $\mathrm{EF}$ & $\mathrm{EF}$ & EF & $\mathrm{EF}$ & $\mathrm{EF}$ & $\mathrm{EF}$ & $\mathrm{EF}$ & & \\
\hline $\mathrm{CO}_{2}$ & 1767 & 1728 & 1545 & 1640 & 1636 & 1723 & 1631 & 1722 & 1729 & 1603 & 1679 & 1689 & 1628 & 1577 & 1664 & 66 & 1664 \\
\hline $\mathrm{CO}$ & 34.66 & 64.45 & 146.34 & 101.68 & 105.38 & 58.27 & 80.04 & 57.63 & 50.38 & 123.20 & 67.25 & 71.74 & 102.17 & 134.70 & 85.56 & 33.75 & 85.56 \\
\hline NO & bdl & bdl & bdl & 2.348 & bdl & bdl & bdl & bdl & bdl & 3.206 & 1.960 & 1.322 & bdl & bdl & 2.209 & 0.788 & 2.063 \\
\hline $\mathrm{NO}_{2}$ & 3.566 & bdl & bdl & 1.022 & bdl & 5.355 & 4.457 & 7.077 & 4.550 & 4.753 & 1.253 & 1.275 & bdl & bdl & 3.701 & 2.110 & 3.482 \\
\hline $\mathrm{NO}_{\mathrm{x}}$ as $\mathrm{NO}$ & 2.325 & bdl & bdl & 3.014 & bdl & 3.492 & 2.907 & 4.615 & 2.968 & 5.673 & 2.777 & 2.154 & bdl & bdl & 3.325 & 1.133 & 3.637 \\
\hline $\mathrm{CH}_{4}$ & 0.859 & bdl & 16.422 & 6.458 & 4.417 & 1.726 & 9.648 & 1.471 & 2.067 & 5.131 & 4.402 & 2.709 & 5.169 & 6.730 & 5.170 & 4.200 & 5.008 \\
\hline $\mathrm{C}_{2} \mathrm{H}_{4}$ & 0.623 & bdl & bdl & 1.453 & 1.235 & 0.932 & 1.465 & 0.526 & 0.594 & 0.962 & 0.761 & 0.746 & 1.512 & 2.485 & 1.108 & 0.561 & 1.155 \\
\hline $\mathrm{C}_{2} \mathrm{H}_{2}$ & 0.193 & bdl & bdl & 0.340 & 0.218 & bdl & 0.292 & 0.144 & 0.139 & bdl & 0.234 & 0.202 & 0.175 & 0.319 & 0.226 & 0.070 & 0.233 \\
\hline $\mathrm{C}_{2} \mathrm{H}_{6}$ & $\mathrm{~nm}$ & $\mathrm{~nm}$ & $\mathrm{~nm}$ & $\mathrm{~nm}$ & 0.817 & $\mathrm{~nm}$ & 1.476 & 0.153 & 0.190 & bdl & 0.897 & 0.662 & $\mathrm{~nm}$ & $\mathrm{~nm}$ & 0.699 & 0.493 & 0.910 \\
\hline $\mathrm{C}_{3} \mathrm{H}_{6}$ & $\mathrm{~nm}$ & $\mathrm{~nm}$ & $\mathrm{~nm}$ & 0.452 & 0.653 & $\mathrm{~nm}$ & 0.942 & 0.173 & 0.205 & bdl & 0.630 & 0.634 & 0.774 & bdl & 0.558 & 0.267 & 0.496 \\
\hline $\mathrm{HCHO}$ & 1.979 & bdl & bdl & 0.523 & bdl & bdl & bdl & bdl & bdl & bdl & bdl & bdl & 2.485 & 2.467 & 1.864 & 0.924 & 1.845 \\
\hline $\mathrm{CH}_{3} \mathrm{OH}$ & bdl & bdl & 3.640 & 4.297 & 5.506 & 0.251 & 4.397 & 1.892 & 0.766 & 3.530 & 2.034 & 1.704 & 3.704 & 2.448 & 2.847 & 1.582 & 2.665 \\
\hline $\mathrm{CH}_{3} \mathrm{COOH}$ & 0.890 & bdl & 4.183 & 0.600 & bdl & bdl & 4.643 & 6.476 & 7.070 & bdl & 3.250 & 2.388 & 9.151 & 6.486 & 4.514 & 2.798 & 4.523 \\
\hline $\mathrm{HCOOH}$ & 0.682 & 1.933 & 1.125 & 0.554 & bdl & bdl & 1.838 & 0.294 & 1.780 & bdl & bdl & bdl & 0.285 & 0.526 & 1.002 & 0.683 & 1.003 \\
\hline $\mathrm{NH}_{3}$ & 0.142 & 1.613 & 4.015 & 1.658 & bdl & bdl & 0.910 & 3.902 & 1.393 & bdl & 0.350 & 0.339 & 1.539 & 2.827 & 1.699 & 1.354 & 1.755 \\
\hline $\mathrm{HCN}$ & 0.721 & bdl & bdl & 0.019 & bdl & 0.476 & bdl & bdl & bdl & bdl & 0.277 & bdl & bdl & bdl & 0.373 & 0.298 & 0.158 \\
\hline propane & $\mathrm{nm}$ & $\mathrm{nm}$ & $\mathrm{nm}$ & $\mathrm{nm}$ & 0.283 & $\mathrm{~nm}$ & 0.436 & 0.040 & 0.054 & $\mathrm{~nm}$ & 0.256 & 0.184 & $\mathrm{~nm}$ & $\mathrm{~nm}$ & 0.209 & 0.150 & 0.282 \\
\hline isobutane & $\mathrm{nm}$ & $\mathrm{nm}$ & $\mathrm{nm}$ & $\mathrm{nm}$ & 0.030 & $\mathrm{~nm}$ & 0.032 & 0.003 & 0.004 & $\mathrm{~nm}$ & 0.020 & 0.012 & $\mathrm{~nm}$ & $\mathrm{~nm}$ & 0.017 & 0.013 & 0.025 \\
\hline n-butane & $\mathrm{nm}$ & $\mathrm{nm}$ & $\mathrm{nm}$ & $\mathrm{nm}$ & 0.086 & $\mathrm{~nm}$ & 0.097 & 0.009 & 0.014 & $\mathrm{~nm}$ & 0.045 & 0.048 & $\mathrm{~nm}$ & $\mathrm{~nm}$ & 0.050 & 0.036 & 0.072 \\
\hline $\mathrm{t}$-2-butene & $\mathrm{nm}$ & $\mathrm{nm}$ & $\mathrm{nm}$ & $\mathrm{nm}$ & 0.057 & $\mathrm{~nm}$ & 0.089 & 0.011 & 0.012 & $\mathrm{~nm}$ & 0.057 & 0.034 & $\mathrm{~nm}$ & $\mathrm{~nm}$ & 0.043 & 0.030 & 0.057 \\
\hline 1-butene & $\mathrm{nm}$ & $\mathrm{nm}$ & $\mathrm{nm}$ & $\mathrm{nm}$ & 0.138 & $\mathrm{~nm}$ & 0.195 & 0.041 & 0.044 & $\mathrm{~nm}$ & 0.127 & 0.080 & $\mathrm{~nm}$ & $\mathrm{~nm}$ & 0.104 & 0.060 & 0.134 \\
\hline isobutene & $\mathrm{nm}$ & $\mathrm{nm}$ & $\mathrm{nm}$ & $\mathrm{nm}$ & 0.120 & $\mathrm{~nm}$ & 0.176 & 0.022 & 0.031 & $\mathrm{~nm}$ & 0.117 & 0.064 & $\mathrm{~nm}$ & $\mathrm{~nm}$ & 0.088 & 0.060 & 0.117 \\
\hline c-2-butene & $\mathrm{nm}$ & $\mathrm{nm}$ & $\mathrm{nm}$ & $\mathrm{nm}$ & 0.043 & $\mathrm{~nm}$ & 0.067 & 0.008 & 0.009 & $\mathrm{~nm}$ & 0.043 & 0.025 & $\mathrm{~nm}$ & $\mathrm{~nm}$ & 0.033 & 0.023 & 0.043 \\
\hline cyclopentane & $\mathrm{nm}$ & $\mathrm{nm}$ & $\mathrm{nm}$ & $\mathrm{nm}$ & $2 \times 10^{-3}$ & $\mathrm{~nm}$ & $3 \times 10^{-3}$ & $1 \times 10^{-4}$ & $4 \times 10^{-4}$ & $\mathrm{~nm}$ & $2 \times 10^{-3}$ & $1 \times 10^{-3}$ & $\mathrm{~nm}$ & $\mathrm{~nm}$ & $1.5 \times 10^{-3}$ & $1.2 \times 10^{-3}$ & $1.9 \times 10^{-3}$ \\
\hline isopentane & $\mathrm{nm}$ & $\mathrm{nm}$ & $\mathrm{nm}$ & $\mathrm{nm}$ & 0.034 & $\mathrm{~nm}$ & 0.014 & 0.001 & bdl & $\mathrm{nm}$ & 0.010 & 0.010 & $\mathrm{~nm}$ & $\mathrm{~nm}$ & 0.014 & 0.012 & 0.020 \\
\hline n-pentane & $\mathrm{nm}$ & $\mathrm{nm}$ & $\mathrm{nm}$ & $\mathrm{nm}$ & 0.032 & $\mathrm{~nm}$ & 0.030 & 0.003 & 0.005 & $\mathrm{~nm}$ & 0.020 & 0.014 & $\mathrm{~nm}$ & $\mathrm{~nm}$ & 0.017 & 0.012 & 0.025 \\
\hline 1,3 butadiene & $\mathrm{nm}$ & $\mathrm{nm}$ & $\mathrm{nm}$ & $\mathrm{nm}$ & 0.175 & $\mathrm{~nm}$ & 0.214 & 0.033 & 0.057 & $\mathrm{~nm}$ & 0.130 & 0.072 & $\mathrm{~nm}$ & $\mathrm{~nm}$ & 0.114 & 0.072 & 0.151 \\
\hline $\mathrm{PM}_{2.5}$ & $\mathrm{~nm}$ & $\mathrm{~nm}$ & $\mathrm{~nm}$ & $\mathrm{~nm}$ & $\mathrm{~nm}$ & 3.79 & 6.52 & $\mathrm{~nm}$ & $\mathrm{~nm}$ & 5.78 & 7.06 & 3.87 & 10.14 & $\mathrm{~nm}$ & 6.19 & 2.36 & 6.26 \\
\hline $\mathrm{H}_{2}$ & $\mathrm{~nm}$ & $\mathrm{~nm}$ & $\mathrm{~nm}$ & $\mathrm{~nm}$ & $\mathrm{~nm}$ & $\mathrm{~nm}$ & $\mathrm{~nm}$ & $\mathrm{~nm}$ & $\mathrm{~nm}$ & 4.76 & 1.66 & 1.68 & $\mathrm{~nm}$ & $\mathrm{~nm}$ & 2.70 & 1.78 & 2.59 \\
\hline
\end{tabular}

Note: "nm" indicates not measured, "bdl" indicates the mixing ratio was below the detection limit, but the EF value may not be low (see Sect. 2.3).

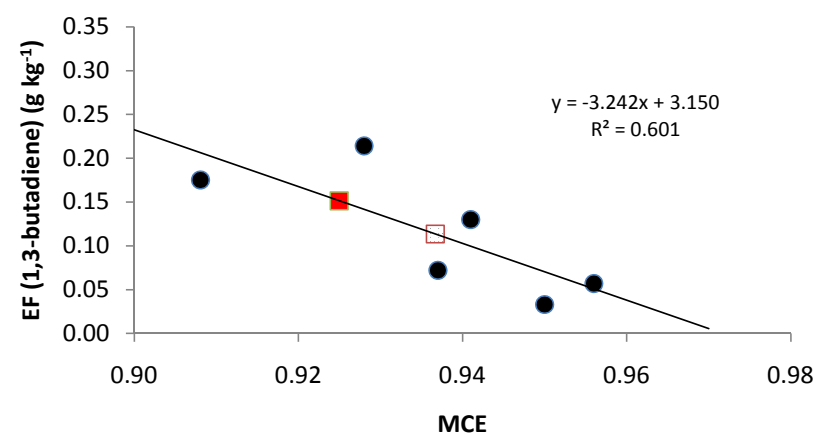

Fig. 2. The solid black circles show all $6 \mathrm{EF}$ measurements on crop residue fires for 1,3-butadiene, and the open red square shows the average of those measurements $\left(0.114 \mathrm{~g} \mathrm{~kg}^{-1}\right)$. The filled red square is the EF for 1,3-butadiene $\left(0.151 \mathrm{~g} \mathrm{~kg}^{-1}\right)$ computed from the fit at the average MCE for all 14 crop residue fires sampled in Mexico. The value from the fit is $32 \%$ larger, more consistent with the average MCE, and likely better reflects the average EF (see text).

some of the fires. In general, we recommend using the EF computed at the average MCE for each vegetation fire type although in four cases in this study the single EF measurement made for a species for a fire type has to suffice.

The EF for total $\mathrm{PM}_{2.5}$ was measured on many of the CR fires and these EF are also shown in Table 2 along with a recommended average EFPM $_{2.5}$ computed at the average MCE. Particle chemistry details for the CR fires sampled from the ground are shown in Table 4 of Christian et al. (2010) (e.g. $\mathrm{EF}$ for metals, elemental carbon (EC), organic carbon (OC), and several anhydrosugars of potential value as smoke markers). In addition, particle chemistry details (major inorganic species, organic aerosol, and black carbon) are shown in Table 3 of Yokelson et al. (2009) for fires \#1 and \#3 sampled on March 23 and those 2 fires were very likely CR fires.

\subsubsection{Tropical dry forest (TDF) fires}

In Table 3 we show the EF for 6 tropical dry forest deforestation fires sampled from the air in the Yucatan lowlands that were already presented in Yokelson et al. (2009) and the EF for 3 additional tropical dry forest fires that were sampled in more mountainous areas of southern Mexico (see Table 1 or Fig. 1). We have combined all the data and implemented the $\mathrm{EF}$ versus MCE regression based approach described above to generate a set of best estimate EF for Mexican tropical dry forest (TDF) fires. The EF published previously for the TDF fires in the Yucatan (Yokelson et al., 2009) and the "allMexico" values are very similar, in part because the Yucatan fires account for most of the combined TDF data. The new TDF data now include EF for ethyne and formic acid, which were not available from the Yucatan data. However, these $\mathrm{EF}$ are based on only one fire in each case. While most of the national average EF are similar to the Yucatan EF, the national average $\mathrm{EF}$ is much higher for $\mathrm{NH}_{3}$ driven by the large $\mathrm{EFNH}_{3}$ obtained for the two TDF fires sampled on 11 March 2006 (Table 3). These two TDF fires differed from the 
Table 3. Emission factors (EF, $\mathrm{g} \mathrm{kg}^{-1}$ ) and modified combustion efficiency (MCE) for tropical dry forest fires.

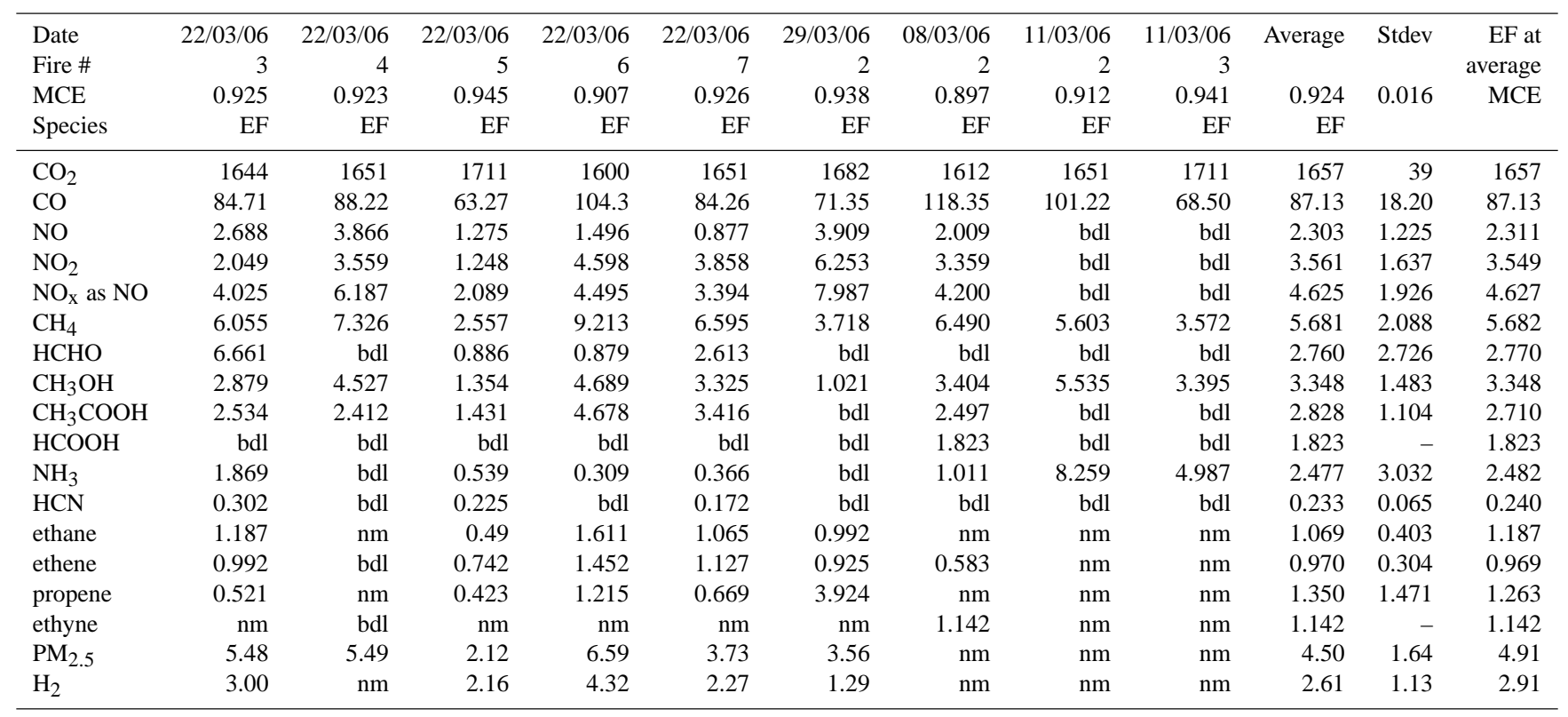

Note: "nm" indicates not measured, "bdl" indicates the mixing ratio was below the detection limit, but the EF value may not be low (see Sect. 2.3 ).

Table 4. Emission factors (EF, $\mathrm{g} \mathrm{kg}^{-1}$ ) and modified combustion efficiency (MCE) for fires burning mixed crop residue and tropical dry forest.

\begin{tabular}{lrrrrrrrr}
\hline Date & $22 / 03 / 06$ & $22 / 03 / 06$ & $22 / 03 / 06$ & $29 / 03 / 06$ & $29 / 03 / 06$ & Average & Stdev & $\begin{array}{r}\text { EF at } \\
\text { average } \\
\text { Fire \# }\end{array}$ \\
$\mathrm{MCE}$ & 1 & 2 & 8 & 1 & 3 & & & \\
Species & $\mathrm{EF}$ & $\mathrm{EF}$ & $\mathrm{EF}$ & $\mathrm{EF}$ & $\mathrm{EF}$ & $\mathrm{EF}$ & & \\
\hline $\mathrm{CO}_{2}$ & 1607 & 1627 & 1671 & 1656 & 1695 & 1651 & 35 & 1651 \\
$\mathrm{CO}$ & 114.4 & 96.76 & 72.25 & 82.44 & 68.13 & 86.80 & 18.98 & 86.80 \\
$\mathrm{NO}$ & 4.780 & 1.620 & 5.386 & 2.412 & 6.345 & 4.109 & 2.010 & 4.109 \\
$\mathrm{NO}_{2}$ & 11.510 & 2.360 & 12.430 & 4.818 & 9.669 & 8.157 & 4.374 & 8.157 \\
$\mathrm{NO}_{\mathrm{x}}$ as NO & 12.290 & 3.159 & 13.490 & 4.568 & 12.650 & 9.231 & 4.945 & 9.232 \\
$\mathrm{CH}_{4}$ & 7.349 & 6.302 & 4.151 & 3.517 & 4.883 & 5.240 & 1.570 & 5.241 \\
$\mathrm{HCHO}$ & $\mathrm{bdl}$ & 3.136 & $\mathrm{bdl}$ & $\mathrm{bdl}$ & $\mathrm{bdl}$ & 3.136 & - & 3.136 \\
$\mathrm{CH}_{3} \mathrm{OH}$ & 3.834 & 3.168 & 2.376 & 1.694 & 1.336 & 2.482 & 1.030 & 2.482 \\
$\mathrm{CH}_{3} \mathrm{COOH}$ & $\mathrm{bdl}$ & 3.544 & $\mathrm{bdl}$ & 6.359 & $\mathrm{bdl}$ & 4.952 & 1.991 & 5.558 \\
$\mathrm{NH}_{3}$ & 0.626 & 0.080 & 1.675 & $\mathrm{bdl}$ & $\mathrm{bdl}$ & 0.794 & 0.811 & 1.007 \\
$\mathrm{HCN}$ & $\mathrm{bdl}$ & 0.102 & 0.449 & $\mathrm{bdl}$ & 0.250 & 0.267 & 0.174 & 0.204 \\
ethane & $\mathrm{nm}$ & $\mathrm{bdl}$ & 0.668 & 0.866 & $\mathrm{~nm}$ & 0.767 & 0.140 & 0.941 \\
ethene & $\mathrm{bdl}$ & $\mathrm{bdl}$ & 1.065 & 0.813 & 0.433 & 0.770 & 0.318 & 0.998 \\
propene & $\mathrm{nm}$ & $\mathrm{bdl}$ & 0.845 & 1.386 & $\mathrm{~nm}$ & 1.116 & 0.383 & 1.590 \\
ethyne & $\mathrm{bdl}$ & $\mathrm{bdl}$ & $\mathrm{bdl}$ & 0.295 & $\mathrm{bdl}$ & 0.295 & - & 0.295 \\
$\mathrm{H}_{2}$ & $\mathrm{~nm}$ & 1.92 & 2.37 & 1.44 & $\mathrm{~nm}$ & 1.91 & 0.47 & 1.86 \\
$\mathrm{PM}_{2.5}$ & 8.29 & 8.83 & 10.06 & 6.21 & 5.69 & 7.82 & 1.83 & 7.82 \\
\hline
\end{tabular}

Note: "nm" indicates not measured, "bdl" indicates the mixing ratio was below the detection limit, but the EF value may not be low (see Sect. 2.3). 
seven other TDF fires we sampled in that they were burning understory vegetation in an un-slashed forest. Based on our airborne observations both small deforestation and small understory fires are common in Mexico and nearly all BB emission models (e.g. FINNv1, see Sect. 3.3) are based on moderate resolution remote sensing data or vegetation maps that cannot differentiate between small fires of these two types. Thus, including EF from both types in the national average is appropriate. However, a straight average of all our TDF fire samples is equivalent to assuming that $\sim 22 \%$ of TDF fires are understory fires and the actual relative frequency of these two fire types at the national scale could differ from what we observed during our one-month airborne search for fires. If the larger $\mathrm{EFNH}_{3}$ for understory fires was due to higher $\mathrm{N}$ content in the understory fuels, we would expect a similar increase in $\mathrm{EFNO}_{\mathrm{x}}$ for understory fires (Burling et al., 2010). However, $\mathrm{NO}_{\mathrm{x}}$ was below the detection limits for the TDF understory fires we sampled. A lower $\mathrm{NO}_{\mathrm{x}} / \mathrm{NH}_{3}$ ratio is sometimes associated with lower MCE (Goode et al., 2000; McMeeking et al., 2009), but the average MCE for the understory fires $(0.926 \pm 0.014)$ was not significantly different from the average MCE for the deforestation fires $(0.924 \pm 0.016)$. Finally, we note that Fire \#2 sampled on 23 March of 2006 by the NCAR C-130 was probably a TDF deforestation fire and the emissions of several trace gas and particle species from that fire that were not measured on the Twin Otter are reported in Table 3 of Yokelson et al. (2009).

In addition to tropical dry forest, Mexico has remnants of a formerly larger tropical evergreen forest on each coast (Hughes et al., 2000; Jaramillo et al., 2003). We did not locate or sample any fires in the Mexican tropical evergreen forest during our mission. However, Yokelson et al. (2009) noted that the EF they measured for tropical dry forest fires in Mexico are very similar to the EF measured for tropical evergreen forests in Brazil (Ferek et al 1998; Yokelson et al., 2008). Thus, we assume that the EF we report here for Mexican tropical dry forest fires are applicable to fires in Mexican tropical evergreen forests.

\subsubsection{Mixed crop residue and tropical dry forest fires}

During the March 2006 airborne fire sampling in the Yucatan it was often observed that high surface windspeeds contributed to crop residue fires escaping into the adjacent tropical dry forest where they burned mostly understory fuels. The results for the fires associated with this scenario were included in Table 2 of Yokelson et al. (2009). In Table 4 we now present these fires as their own category and derive average EF values using the EF versus MCE regression based procedure described above. One might expect that the emissions from these mixed CR/TDF fires would be intermediate between the CR and TDF types. This is observed for a few compounds like methane and ethane, but not for many others. For instance, the mixed fire type has significantly larger EF for $\mathrm{NO}_{\mathrm{x}}$ and acetic acid and significantly lower $\mathrm{EF}$ for $\mathrm{NH}_{3}$ than either component fire type. The lower $\mathrm{EF}$ for $\mathrm{NH}_{3}$ is surprising since the largest $\mathrm{EFNH}_{3}$ of the TDF fires were from the 11 March TDF understory fires, which burned nominally similar understory fuels as in the forest on the margins of the crop residue fires. The increase in $\mathrm{EFNO}_{\mathrm{x}}$ by more than a factor of two would also not be predicted by combining contributions from the two fuel types involved, especially since $\mathrm{NO}_{\mathrm{x}}$ was below detection limits for the 11 March TDF understory fires. The three fire types had almost identical MCE and there was no seasonal trend in the $\mathrm{EF}$ for $\mathrm{N}$-species during our month of sampling. Thus, it is possible that factors other than "fuel type", MCE, or fuel moisture; such as surface windspeed, may contribute significantly to the mix of emissions produced in open burning. We emphasize that a link between windspeed and $\mathrm{NO}_{\mathrm{x}}$ emissions is speculation at this point. One possible mechanism for this could be that wind promotes flaming combustion of vegetation elements that are known to have high levels of $\mathrm{N}$, but may be too moist to burn in the absence of wind such as live foliage. Additional, targeted research would be required to establish and quantify a connection between surface windspeed and fire emissions, but if a useful correlation was found it could be feasible to incorporate it in models since the windspeed data is widely available and already commonly used to model sea salt emissions (e.g. Gong et al., 1997).

\subsubsection{Savanna fires}

We sampled 8 savanna fires from the air during March 2006 in the Mexican states of Chiapas and Guerrero that have not been previously published and the EF are shown in Table 5. We derived study-average EF values at the average MCE as described above. These March 2006 fires occurred during the early part of the dry season and may have burned in fuels that had a higher moisture and nitrogen content than is common during the late dry season. Thus, we compare our Mexican early dry season savanna fire EF to those obtained relatively later in the dry season on African savanna fires using similar instrumentation and/or sampling methods (Yokelson et al., 2003; Sinha et al., 2003). Table 5 shows that our "early dry" central EF values are 1.7 (or more) times higher for both $\mathrm{NO}_{\mathrm{x}}$ and nearly all the observed smoldering species, namely $\mathrm{H}_{2}, \mathrm{NH}_{3}, \mathrm{CH}_{3} \mathrm{OH}, \mathrm{CH}_{3} \mathrm{COOH}, \mathrm{C}_{2} \mathrm{H}_{6}$, $\mathrm{C}_{3} \mathrm{H}_{6}$, and $\mathrm{CH}_{4}$. The early dry MCE is lower so we expect a higher EFPM $_{2.5}$ (Yokelson et al., 2007a). However, our early dry season $\mathrm{EFPM}_{2.5}$ of $7.6 \pm 2.5 \mathrm{~g} \mathrm{~kg}^{-1}$ is below the African late dry season EFPM $_{4}$ of $10.0 \pm 7.5 \mathrm{~g} \mathrm{~kg}^{-1}$ (Sinha et al., 2003). If we take the average of the African late dry season value with the Brazilian late dry season savanna fire $\mathrm{EFPM}_{4}$ of $3.86 \pm 0.36 \mathrm{~g} \mathrm{~kg}^{-1}$ (Akagi et al., 2011) we obtain $\sim 6.93 \mathrm{~g} \mathrm{~kg}^{-1}$, which is close to our early dry season value of $\sim 7.6 \mathrm{~g} \mathrm{~kg}^{-1}$. HCHO was the only NMOC we observed to have a much lower EF for the early dry season savanna fires, but the decrease is based on just two EF in the present study. EFHCN did not change, indicating that $\mathrm{HCN}$ 
Table 5. Emission factors (EF, $\mathrm{g} \mathrm{kg}^{-1}$ ) and modified combustion efficiency (MCE) measured for early dry season savanna fires in Mexico compared to late dry season data from Africa.

\begin{tabular}{|c|c|c|c|c|c|c|c|c|c|c|c|c|c|}
\hline Date & $20 / 3 / 06$ & $20 / 3 / 06$ & $27 / 3 / 06$ & $27 / 3 / 06$ & $27 / 3 / 06$ & $27 / 3 / 06$ & $27 / 3 / 06$ & $27 / 3 / 06$ & Average & Stdev & EF at & Africa ${ }^{1}$ & Mex/Afr \\
\hline Fire \# & 4 & 5 & 2 & 3 & 4 & 5 & 6 & 7 & & & average & & \\
\hline MCE & 0.934 & 0.928 & 0.963 & 0.914 & 0.940 & 0.924 & 0.914 & 0.923 & 0.930 & 0.016 & MCE & 0.938 & 0.99 \\
\hline Species & $\mathrm{EF}$ & $\mathrm{EF}$ & $\mathrm{EF}$ & $\mathrm{EF}$ & $\mathrm{EF}$ & $\mathrm{EF}$ & $\mathrm{EF}$ & $\mathrm{EF}$ & $\mathrm{EF}$ & & & & \\
\hline $\mathrm{CO}_{2}$ & 1671 & 1667 & 1740 & 1625 & 1678 & 1626 & 1623 & 1652 & 1660 & 39.02 & 1660 & 1703 & 0.97 \\
\hline $\mathrm{CO}$ & 75.61 & 82.17 & 42.02 & 97.49 & 67.70 & 84.56 & 96.66 & 87.99 & 79.28 & 18.05 & 79.28 & 71.5 & 1.11 \\
\hline $\mathrm{NO}$ & 3.672 & 4.104 & bdl & bdl & 3.648 & bdl & bdl & 5.100 & 4.131 & 0.679 & 4.217 & - & - \\
\hline $\mathrm{NO}_{2}$ & 2.870 & 1.257 & bdl & 9.416 & 4.974 & bdl & 8.426 & 5.660 & 5.434 & 3.134 & 4.457 & - & - \\
\hline $\mathrm{NO}_{\mathrm{x}}$ as $\mathrm{NO}$ & 5.544 & 4.924 & bdl & 6.141 & 6.893 & bdl & 5.495 & 7.191 & 6.031 & 0.877 & 6.093 & 3.37 & 1.81 \\
\hline $\mathrm{CH}_{4}$ & 3.450 & 3.665 & bdl & 5.532 & 3.431 & 4.442 & 5.506 & 2.852 & 4.126 & 1.061 & 3.739 & 2.19 & 1.71 \\
\hline $\mathrm{C}_{2} \mathrm{H}_{4}$ & 0.892 & 0.760 & 1.466 & 0.845 & 0.312 & 0.922 & 0.741 & 1.366 & 0.913 & 0.364 & 0.913 & 1.19 & 0.77 \\
\hline $\mathrm{C}_{2} \mathrm{H}_{2}$ & 0.364 & 0.399 & bdl & 0.058 & 0.248 & 0.151 & 0.096 & 0.038 & 0.193 & 0.146 & 0.243 & 0.26 & 0.94 \\
\hline $\mathrm{C}_{2} \mathrm{H}_{6}$ & 1.336 & 0.589 & $\mathrm{~nm}$ & 2.504 & 1.649 & $\mathrm{~nm}$ & 1.082 & bdl & 1.432 & 0.714 & 1.371 & 0.21 & 6.53 \\
\hline $\mathrm{C}_{3} \mathrm{H}_{6}$ & 0.446 & 0.333 & 2.303 & bdl & 1.298 & 6.346 & 2.126 & 3.969 & 2.403 & 2.138 & 2.474 & 0.23 & 10.8 \\
\hline $\mathrm{HCHO}$ & 0.229 & bdl & bdl & bdl & bdl & bdl & bdl & 1.363 & 0.796 & 0.802 & 0.598 & 1.06 & 0.56 \\
\hline $\mathrm{CH}_{3} \mathrm{OH}$ & 1.966 & 2.035 & bdl & 2.673 & 1.562 & 0.992 & 2.341 & 3.661 & 2.176 & 0.849 & 1.991 & 1.17 & 1.70 \\
\hline $\mathrm{CH}_{3} \mathrm{COOH}$ & bdl & bdl & 3.440 & bdl & 4.217 & 9.391 & bdl & bdl & 5.683 & 3.235 & 7.503 & 2.42 & 3.10 \\
\hline $\mathrm{HCOOH}^{2}$ & 0.137 & 0.350 & bdl & bdl & bdl & bdl & bdl & bdl & 0.244 & 0.151 & 0.273 & 0.295 & 0.92 \\
\hline $\mathrm{NH}_{3}$ & 0.730 & 0.495 & bdl & bdl & bdl & bdl & bdl & 0.205 & 0.477 & 0.263 & 0.572 & 0.28 & 2.04 \\
\hline $\mathrm{HCN}$ & 0.690 & 0.636 & 0.202 & bdl & 0.767 & bdl & bdl & 0.199 & 0.499 & 0.276 & 0.533 & 0.53 & 1.01 \\
\hline $\mathrm{PM}_{2.5}$ & 8.11 & 6.48 & 3.96 & 10.20 & 7.76 & 9.39 & 10.84 & 4.43 & 7.65 & 2.54 & 7.65 & 10.0 & 0.77 \\
\hline $\mathrm{H}_{2}$ & 1.62 & 2.05 & $\mathrm{~nm}$ & 2.56 & 1.22 & $\mathrm{~nm}$ & 2.78 & 1.38 & 1.93 & 0.64 & 1.70 & 0.97 & 1.76 \\
\hline
\end{tabular}

1 African late dry season savanna fire emission factors for ethane, propene, and $\mathrm{PM}_{2.5}$ from Sinha et al. (2003); $\mathrm{H}_{2}$ from Andreae and Merlet (2001); remainder Yokelson et al. (2003).

2 The formic acid emission factor from Yokelson et al. (2003) was scaled to reflect new reference data (see text).

Note: "nm" indicates not measured, "bdl" indicates the mixing ratio was below the detection limit, but the EF value may not be low (see Sect. 2.3).

might arise from a non-seasonally varying nitrogen containing compound in the biomass. We note that the seasonal comparison for savanna fires contrasts the tropical forest fire seasonal comparison in Yokelson et al. (2009) where early dry season forest fires had EF for trace gases that were similar to late season forest fires, but $\mathrm{EF}$ for $\mathrm{PM}_{2.5}$ that were much lower than for late season forest fires. The lower EFPM $_{2.5}$ for early dry season forest fires could be related to reduced fire intensity (Yokelson et al., 2009; Reid et al., 1998 and references therein).

In a previous study of seasonal effects on savanna fire emissions, Korontzi et al. (2003) also reported higher EF for fires burning early in the dry season (in Africa) for a few smoldering compounds. Those authors found that the early and late dry season EF both followed one trend with MCE. The difference in EF in their case could be explained by a difference in MCE. In contrast, we find that the EF for early season fires lie well above the trend established by late dry season fires for several compounds $\left(\mathrm{CH}_{4}, \mathrm{CH}_{3} \mathrm{OH}\right.$, and $\left.\mathrm{NO}_{\mathrm{x}}\right)$ as shown in Fig. 3. This latter finding could be at least partly due to differences between the fuels in African and Mexican savannas. In summary, so far all observations are consistent with a scenario in which early dry season savanna fires have lower MCE and higher EF for $\mathrm{NH}_{3}, \mathrm{NO}_{\mathrm{x}}$, and the NMOC produced by smoldering. The larger emissions of $\mathrm{NO}_{\mathrm{x}}$ and NMOC could potentially impact the formation of secondary organic aerosol (Grieshop et al., 2009; Alvarado and Prinn, 2009) and $\mathrm{O}_{3}$ (Trentmann et al., 2005).

\subsubsection{Pine-oak forest fires}

In Table 6 we present the EF measured during March 2006 for 7 pine-oak forest fires in remote mountain locations. Most of these fires were understory fires like those in the MCMA area previously described by Yokelson et al. (2007a), but a few in Chiapas were part of land-clearing operations and therefore, the fuel for those fires included relatively more large-diameter wood. We derive EF values at the average MCE for these fires as a group. For comparison, column 12 (Table 6) shows the average EF measured from the air for the 8 mountain pine-oak fires sampled near the MCMA by Yokelson et al. (2007a). Yokelson et al. (2007a) observed significantly larger emissions of $\mathrm{NO}_{\mathrm{x}}$ and $\mathrm{HCN}$ (but not $\mathrm{NH}_{3}$ ) than what was produced during laboratory experiments burning fuels collected in pine forests located in areas of the US not impacted by urban emissions. They speculated that this difference could be due to nitrogen deposition from the MCMA urban plume. Here, we directly compare the emission factors for the MCMA-impacted pine-oak forest fires to our emission factors for rural pine-oak forest fires in Mexico. We find that the $\mathrm{NO}_{\mathrm{x}}$ and $\mathrm{NH}_{3} \mathrm{EF}$ are enhanced in the urban-impacted forests by factors of 2 and 
Table 6. Emission factors (EF, $\mathrm{g} \mathrm{kg}^{-1}$ ) and modified combustion efficiency (MCE) measured in rural pine-oak forests in Mexico compared to data from urban-impacted pine-oak forests in Mexico.

\begin{tabular}{|c|c|c|c|c|c|c|c|c|c|c|c|c|}
\hline $\begin{array}{l}\text { Date } \\
\text { Fire \# }\end{array}$ & $\begin{array}{r}20 / 3 / 06 \\
1\end{array}$ & $\begin{array}{r}20 / 3 / 06 \\
2\end{array}$ & $\begin{array}{r}20 / 3 / 06 \\
3\end{array}$ & $\begin{array}{r}25 / 3 / 06 \\
1\end{array}$ & $\begin{array}{r}27 / 3 / 06 \\
1\end{array}$ & $\begin{array}{r}28 / 3 / 06 \\
1\end{array}$ & $\begin{array}{r}28 / 3 / 06 \\
2\end{array}$ & Average & Stdev & $\begin{array}{r}\mathrm{EF} \text { at } \\
\text { average }\end{array}$ & $\begin{array}{r}\text { Urban } \\
\text { Pine-Oak* }\end{array}$ & $\begin{array}{r}\text { Urban/Rural } \\
\text { Pine-Oak }\end{array}$ \\
\hline MCE & 0.943 & 0.904 & 0.869 & 0.907 & 0.889 & 0.903 & 0.942 & 0.908 & 0.027 & MCE & 0.927 & 1.02 \\
\hline Species & $\mathrm{EF}$ & $\mathrm{EF}$ & $\mathrm{EF}$ & $\mathrm{EF}$ & $\mathrm{EF}$ & $\mathrm{EF}$ & $\mathrm{EF}$ & $\mathrm{EF}$ & & & & \\
\hline $\mathrm{CO}_{2}$ & 1693 & 1593 & 1509 & 1603 & 1549 & 1597 & 1673 & 1603 & 64.351 & 1603 & 1662 & 1.04 \\
\hline $\mathrm{CO}$ & 64.76 & 107.52 & 145.28 & 104.58 & 123.25 & 109.68 & 65.11 & 102.9 & 29.336 & 102.9 & 82.9 & 0.81 \\
\hline NO & 1.903 & 0.711 & 2.370 & 1.635 & 2.410 & 1.070 & 1.128 & 1.604 & 0.663 & 1.604 & - & - \\
\hline $\mathrm{NO}_{2}$ & 1.373 & 4.379 & 3.620 & 2.993 & 3.742 & 4.364 & 1.898 & 3.195 & 1.176 & 3.195 & - & - \\
\hline $\mathrm{NO}_{\mathrm{x}}$ as $\mathrm{NO}$ & 2.798 & 3.566 & 4.731 & 3.432 & 4.850 & 3.916 & 2.309 & 3.658 & 0.936 & 3.657 & 7.44 & 2.03 \\
\hline $\mathrm{CH}_{4}$ & 3.522 & 4.553 & 11.406 & 4.500 & 6.526 & 5.052 & 4.367 & 5.704 & 2.675 & 5.704 & 4.96 & 0.87 \\
\hline $\mathrm{C}_{2} \mathrm{H}_{4}$ & 0.952 & 1.004 & 1.802 & 1.194 & 1.114 & 0.473 & 0.974 & 1.073 & 0.395 & 1.074 & 0.94 & 0.88 \\
\hline $\mathrm{C}_{2} \mathrm{H}_{2}$ & 0.165 & 0.274 & 0.314 & 0.506 & 0.519 & 0.487 & 0.242 & 0.358 & 0.144 & 0.358 & 0.19 & 0.53 \\
\hline $\mathrm{C}_{2} \mathrm{H}_{6}$ & 1.271 & bdl & 3.959 & 1.681 & 1.737 & 0.416 & 1.191 & 1.709 & 1.200 & 1.727 & 0.58 & 0.34 \\
\hline $\mathrm{C}_{3} \mathrm{H}_{6}$ & 1.581 & 4.329 & 1.990 & 1.084 & 3.241 & 0.791 & 1.350 & 2.052 & 1.281 & 2.052 & 0.5 & 0.24 \\
\hline $\mathrm{HCHO}$ & 2.507 & 2.006 & 5.381 & bdl & bdl & bdl & 1.113 & 2.752 & 1.845 & 3.032 & 2.99 & 0.99 \\
\hline $\mathrm{CH}_{3} \mathrm{OH}$ & 1.405 & 2.315 & 4.243 & 3.218 & 3.795 & 3.216 & 1.506 & 2.814 & 1.101 & 2.814 & 2.06 & 0.73 \\
\hline $\mathrm{CH}_{3} \mathrm{COOH}$ & bdl & 0.649 & bdl & bdl & 0.265 & 3.661 & bdl & 1.525 & 1.860 & 2.610 & 3.96 & 1.52 \\
\hline $\mathrm{HCOOH}$ & 0.280 & 1.226 & 1.282 & 0.390 & bdl & 0.176 & 0.065 & 0.570 & 0.541 & 0.615 & 1.243 & 2.02 \\
\hline $\mathrm{NH}_{3}$ & 1.038 & 0.357 & 1.144 & bdl & bdl & 0.046 & 0.006 & 0.518 & 0.541 & 0.539 & 0.91 & 1.69 \\
\hline $\mathrm{HCN}$ & 0.635 & 1.003 & 0.532 & 0.922 & 1.225 & 1.099 & 0.713 & 0.876 & 0.256 & 0.876 & 1.02 & 1.16 \\
\hline $\mathrm{PM}_{2.5}$ & 3.91 & 11.80 & 9.17 & 12.93 & 17.53 & 12.40 & 11.56 & 11.33 & 4.13 & 11.33 & 11.05 & 0.98 \\
\hline $\mathrm{H}_{2}$ & 1.36 & 0.49 & 5.95 & 1.47 & 2.06 & 1.45 & 1.43 & 2.03 & 1.79 & 2.03 & 1.51 & 0.74 \\
\hline
\end{tabular}

* From Yokelson et al. (2007a). Their formic acid emission factor has been normalized to reflect new reference data (see text).

Note: "nm" indicates not measured, "bdl" indicates the mixing ratio was below the detection limit, but the EF value may not be low (see Sect. 2.3 ).

1.7, respectively, but EFHCN is not significantly different. If we calculate average EF for the rural pine-oak fires that do not include the pine-oak fires in Chiapas (20 March, fires \# 1, 2, and 3) where logs may have been a larger component of the fuel, the urban/rural comparison is essentially the same except that the $\mathrm{NH}_{3}$ enhancement for urban-impacted fire emissions increases. Thus, in these three comparisons, the $\mathrm{EFNO}_{\mathrm{x}}$ is consistently elevated by about a factor of two for the urban/deposition impacted forests, but the results for other $\mathrm{N}$-containing species are variable and somewhat inconclusive at this point. As noted above, enhanced $\mathrm{NO}_{\mathrm{x}}$ emissions could impact downwind ozone and aerosol formation.

\subsubsection{Garbage burning}

Open burning of garbage is an important, but poorly quantified source of emissions in developing countries and in some rural areas of developed countries (Christian et al., 2010). During the 2006 airborne campaign we were able to acquire one sample of the emissions from a small dump fire in Cosolapa, a small rural village in Oaxaca state located $\sim 80 \mathrm{~km}$ SW of Veracruz. Christian et al. (2010) reported EF (based on a fuel $\mathrm{C}$ of $40 \%$ ) for 4 garbage burning (GB) fires that were sampled extensively from the ground in the northern MCMA during April-May of 2007. In Table 7 we show all the MILAGRO garbage burning EF along with previously published EF from Lemieux et al. (2000) and recommended EF from AP-42 (USEPA, 1995). In addition to $\mathrm{CO}_{2}$ and
$\mathrm{CO}$ (used to compute MCE), there were three other species measured in both our airborne sample and the ground-based samples from the MCMA. The emission factors for these species $\left(\mathrm{C}_{2} \mathrm{H}_{4}, \mathrm{CH}_{4}\right.$, and $\left.\mathrm{NH}_{3}\right)$ are plotted versus MCE in Fig. 4, which shows that a single, highly-correlated trend couples the airborne and ground-based measurements. However, with only 5 GB fires sampled our average MCE for open burning of garbage is less constrained than for the other fire types. In addition, for almost a quarter of the species measured, we have only one EF, which precludes a regression of EF vs. MCE for those species. Thus, in Table 7 we simply present the average of all our Mexican measurements and also the limited EF data for open burning of garbage from other sources. Additional details and discussion of the chemistry of the particulate emissions from garbage burning can be found in Christian et al. (2010) and in Sect. 3.2, but clearly much more work is needed to determine both the amount of garbage burned and the nature of the emissions.

\subsection{TEM analyses of particle chemistry}

Some key results of the TEM analyses of our Mexican BB samples have already been reported. The particles emitted by mountain pine-oak forest fires near the MCMA were shown to be internally mixed and have high $\mathrm{N}$ content and other properties discussed in Yokelson et al. (2007a). Particles in a plume emitted by a crop residue fire in the Yucatan had more sulfur and tarballs (spherical organic particles that are 

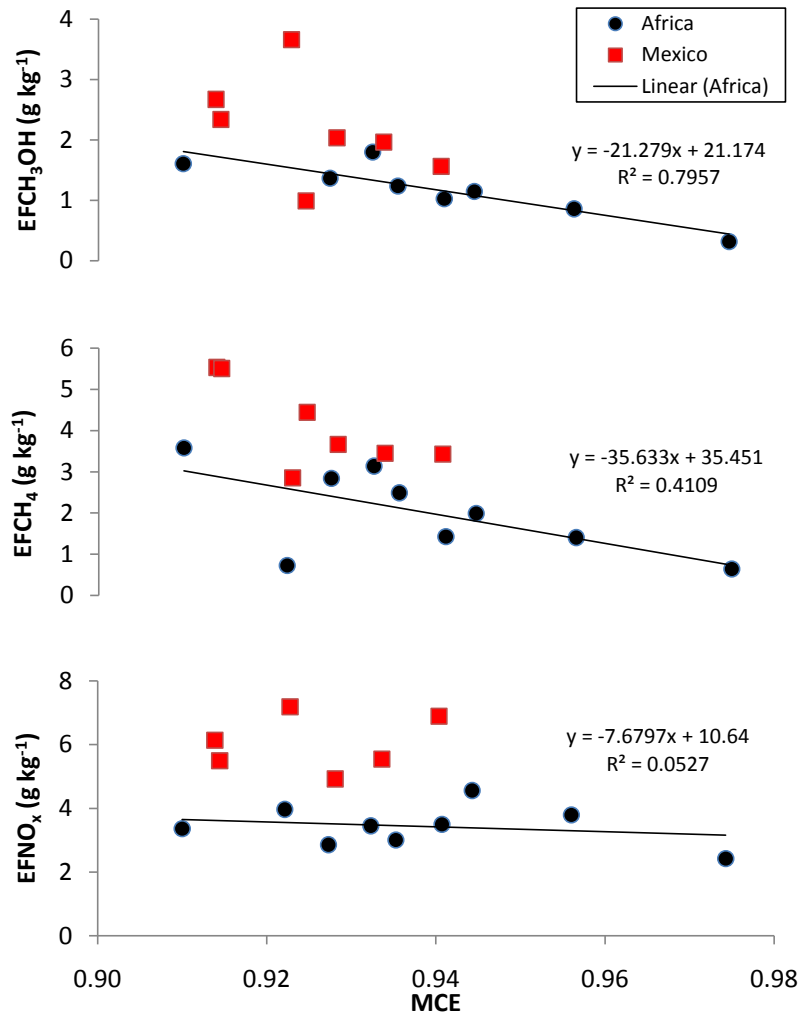

Fig. 3. For several species we show the emission factors measured during the late dry season on savanna fires in Africa (and a fit) for comparison to the emission factors measured on early dry season savanna fires in Mexico. The emission factors for the early dry season fires are higher and lie above the fit for African late season fires for most species as discussed in the text.

assigned a separate category in TEM analyses) and less chloride after that plume had aged for 10-30 min compared to fresh samples of the plume (Yokelson et al., 2009). The compositions, hygroscopicity, and abundance of tarballs were determined by Adachi and Buseck (2011). Here we report additional findings that summarize the body of our 2006 airborne BB TEM samples and also discuss data from two TEM samples containing garbage-burning emissions.

The composition of $\sim 900$ individual, non-volatile aerosol particles from 28 BB samples was analyzed using energydispersive X-ray spectrometry (EDS). Most particles consisted of organic aerosol (OA), tarballs, soot, sulfate, potassium chloride, or mineral dust, and many were internally mixed. Using particle shape as the primary criterion, the distribution of these major species was determined by counting their occurrence in 300 particles from each of 70 samples (collected from 34 fires). On average, $27 \pm 21 \%$ of particles consisted of soot (Fig. 5). As is typical of soot, those particles consist of tens to hundreds of aggregated spherules that contain poorly ordered, curved, graphitic layers. They absorb sunlight and are significant contributors to climate
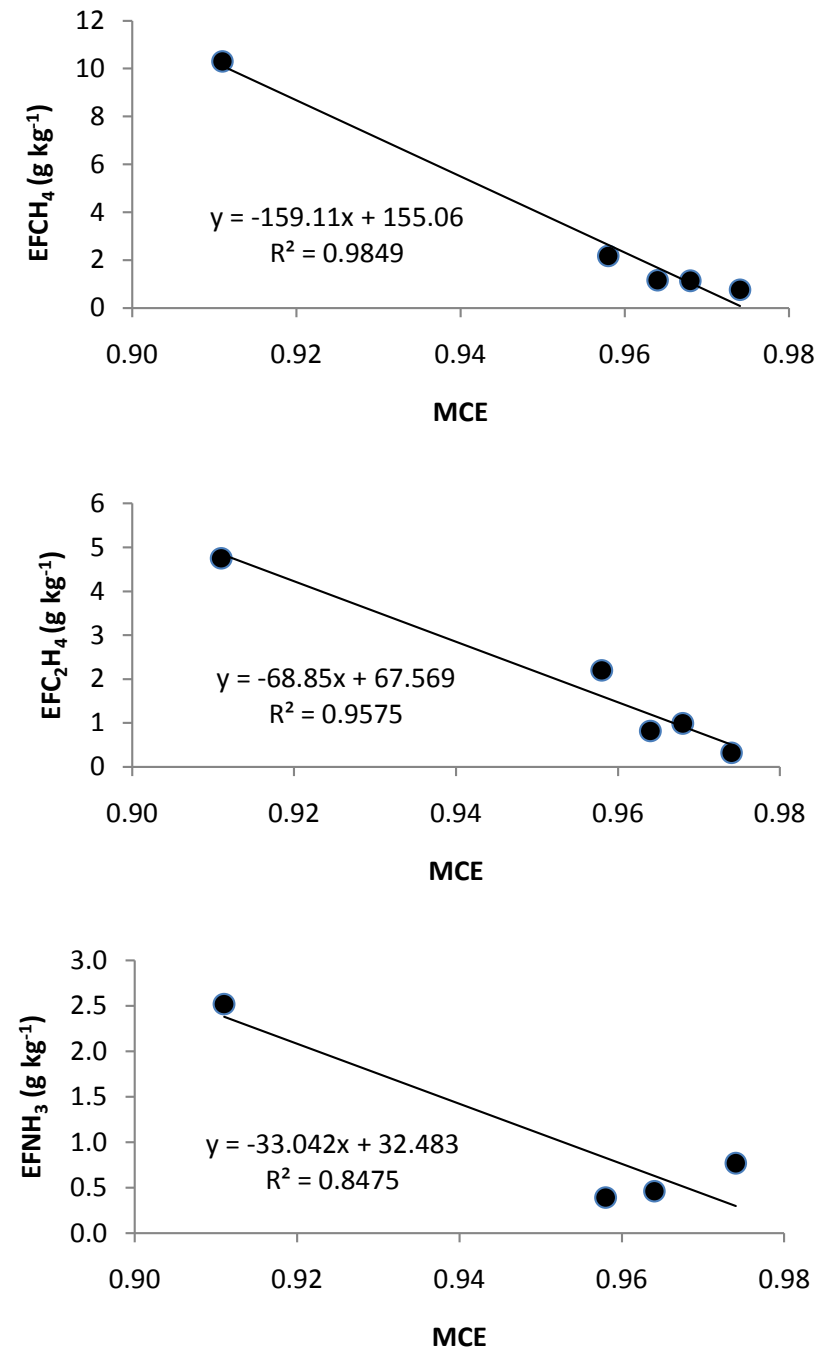

Fig. 4. The 3 species emitted by open garbage burning (in addition to $\mathrm{CO}$ and $\mathrm{CO}_{2}$ ) that have been measured from both the air (the highest MCE point) and the ground fit one trend with MCE, but more measurements of this source are needed.

change (Jacobson, 2001; Chung and Seinfeld, 2002; Adachi et al., 2010). The percentage of particles in a sample that were classified as soot varied even among samples collected from the same fire, reflecting the changing smoke composition that can be emitted by a single fire. The percentage of particles in a sample that were classified as soot increased approximately 4-fold from 15 to $60 \%$ as the sample MCE increased from 0.88 to 0.98 (Fig. 6a). This trend is consistent with previous findings that flaming combustion produces the soot (or black or elemental carbon) produced by fires (e.g. Yokelson et al., 1997; Christian et al., 2003; Reid et al., 2005). Conversely, the fraction of OA particles decreased from about 75 to $30 \%$ over the same MCE range, confirming that smoldering fires produce aerosol with relatively more organic carbon (Fig. 6b). Residual variance not 
Table 7. Emission factors (EF, $\mathrm{g} \mathrm{kg}^{-1}$ ) and modified combustion efficiency (MCE) measured for open burning of garbage in Mexico compared to other work.

\begin{tabular}{|c|c|c|c|c|c|c|c|c|c|}
\hline Date & $25 / 03 / 06$ & $23 / 04 / 07$ & $24 / 04 / 07$ & $25 / 04 / 07$ & $26 / 04 / 07$ & Average & Stdev & AP-42 & Lemieux \\
\hline Fire \# & 2 & 1 & 1 & 1 & 1 & & & & et al. (2000) \\
\hline MCE & 0.974 & 0.964 & 0.911 & 0.958 & 0.968 & 0.955 & 0.025 & & \\
\hline Species & $\mathrm{EF}$ & $\mathrm{EF}$ & $\mathrm{EF}$ & $\mathrm{EF}$ & $\mathrm{EF}$ & $\mathrm{EF}$ & & & \\
\hline $\mathrm{CO}_{2}$ & 1538 & 1404 & 1270 & 1385 & 1409 & 1401 & 95 & & \\
\hline $\mathrm{CO}^{-}$ & 26.09 & 33.80 & 79.10 & 38.70 & 29.60 & 41.46 & 21.56 & 42 & - \\
\hline NO & bdl & bdl & bdl & bdl & bdl & - & - & - & - \\
\hline $\mathrm{NO}_{2}$ & 6.865 & bdl & bdl & bdl & bdl & 6.865 & - & - & - \\
\hline $\mathrm{NO}_{\mathrm{x}}$ as $\mathrm{NO}$ & 4.477 & bdl & bdl & bdl & bdl & 4.477 & - & 3 & - \\
\hline $\mathrm{CH}_{4}$ & 0.766 & 1.16 & 10.3 & 2.18 & 1.14 & 3.109 & 4.054 & 6.5 & - \\
\hline $\mathrm{C}_{2} \mathrm{H}_{4}$ & 0.322 & 0.82 & 4.75 & 2.20 & 0.99 & 1.816 & 1.779 & - & - \\
\hline $\mathrm{C}_{2} \mathrm{H}_{2}$ & bdl & 0.14 & 0.72 & 0.53 & 0.20 & 0.398 & 0.275 & - & - \\
\hline $\mathrm{C}_{3} \mathrm{H}_{6}$ & bdl & 0.36 & 3.34 & 0.97 & 0.36 & 1.258 & 1.418 & - & - \\
\hline $\mathrm{HCHO}$ & bdl & 0.56 & 0.48 & 0.68 & 0.76 & 0.620 & 0.124 & - & - \\
\hline $\mathrm{CH}_{3} \mathrm{OH}$ & bdl & 0.31 & 2.81 & 0.40 & 0.26 & 0.945 & 1.245 & - & - \\
\hline $\mathrm{CH}_{3} \mathrm{COOH}$ & bdl & 0.58 & 7.40 & 0.92 & 0.78 & 2.420 & 3.323 & - & - \\
\hline $\mathrm{HCOOH}$ & bdl & 0.05 & 0.14 & 0.34 & 0.19 & 0.181 & 0.119 & - & - \\
\hline $\mathrm{NH}_{3}$ & 0.768 & 0.46 & 2.52 & 0.39 & bdl & 1.035 & 1.004 & - & - \\
\hline $\mathrm{HCN}$ & 0.473 & bdl & bdl & bdl & bdl & 0.473 & & - & - \\
\hline $\mathrm{HCl}$ & bdl & 1.65 & bdl & 9.80 & 3.02 & 4.82 & 4.36 & - & 2.4 \\
\hline $\mathrm{PM}_{2.5}^{*}$ & bdl & $\mathrm{nm}$ & 20.66 & 5.00 & 5.78 & 10.48 & 8.82 & 8 & 11.3 \\
\hline $\mathrm{H}_{2}$ & 0.091 & $\mathrm{~nm}$ & $\mathrm{~nm}$ & $\mathrm{~nm}$ & $\mathrm{~nm}$ & 0.091 & - & - & - \\
\hline $\mathrm{SO}_{2}$ & $\mathrm{~nm}$ & $\mathrm{~nm}$ & $\mathrm{~nm}$ & $\mathrm{~nm}$ & $\mathrm{~nm}$ & - & - & 0.5 & - \\
\hline
\end{tabular}

* $\mathrm{PM}_{2.5}$ for the 2007 fires in Mexico was estimated as 1.2 times the sum of species measured on quartz filters as described by Christian et al. (2010).

Note: "nm" indicates not measured, "bdl" indicates the mixing ratio was below the detection limit, but the EF value may not be low (see Sect. 2.3 ).

accounted for by MCE is also seen in Fig. 6 as expected. The $\mathrm{OA} / \mathrm{CO}$ emission ratio for smoldering varies by at least a factor of four for biomass combustion (de Gouw and Jimenez, 2009), and the $\mathrm{BC} / \mathrm{CO}_{2}$ emission ratio for turbulent diffusion flames (the type of flames in BB) can vary by a factor of eight just from the degree of flame turbulence alone (Shaddix et al., 1994; Kennedy, 1997).

In addition to the BB samples, two TEM samples that contained smoke from garbage burning were collected. The samples were collected several minutes apart, with the first being pure GB emissions and the second containing the mixed emissions from a crop residue fire and the diluted GB plume. TEM-EDS analysis indicates that their compositions differ (Fig. 7). Sample A in Fig. 7 is of GB and mainly consists of particles containing (a) $\mathrm{Mg}$ and $\mathrm{Ca}$; (b) $\mathrm{Cr}, \mathrm{Fe}$, and $\mathrm{Ni}$; (c) $\mathrm{Al}$; and (d) Si. There are few soot and OA particles. The filter analyses in Table 4 of Christian et al. (2010) also show that garbage burning produced higher levels of $\mathrm{Mg}$ and $\mathrm{Ca}$ than the other types of burning investigated, but $\mathrm{Cr}, \mathrm{Fe}$, and $\mathrm{Ni}$ were not elevated and $\mathrm{Al}$ and $\mathrm{Si}$ were not measured.

Sample B, which was mostly from a CR fire, but also contained some aged GB emissions due to plume mixing, mainly consists of soot, $\mathrm{OA}$, particles containing $\mathrm{Mg}$ and $\mathrm{Ca}$, and their mixtures. Thus, $\mathrm{Mg}$ and $\mathrm{Ca}$ appear to be consistently associated with GB. The glass commonly used for bottles

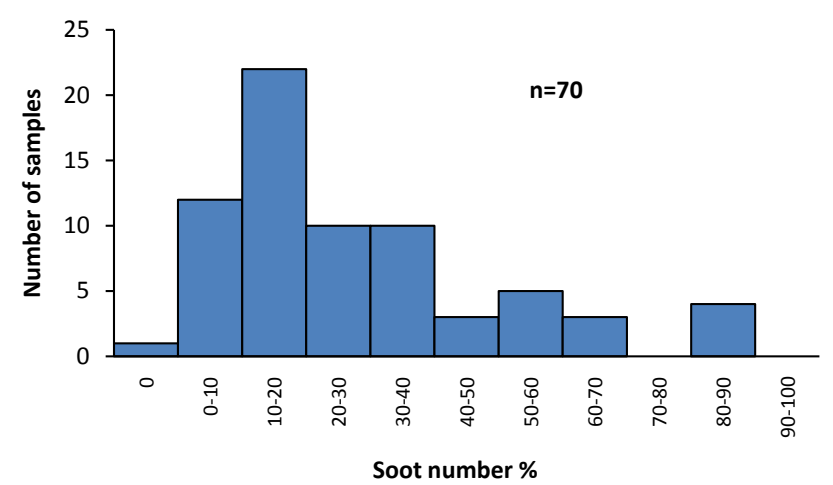

Fig. 5. The number of TEM samples with a percentage of soot particles in the incremental range indicated on the $\mathrm{x}$-axis. On average $27 \pm 21 \%$ of the individual BB particles were identified as soot particles (see Sect. 3.2).

and windows is about $5.7 \% \mathrm{Ca}$ and also contains much $\mathrm{Si}$ and some $\mathrm{Al}$ as a common impurity. Magnesium is the lightest metal widely used in manufacturing, often as $\mathrm{Mg} / \mathrm{Al}$ alloys. About half of the particles in Sample B include Cl. This is consistent with the high $\mathrm{Cl}$ content of particles from garbage burning and crop residue fires observed by Christian et al. (2010), which they suggested is likely due to the 

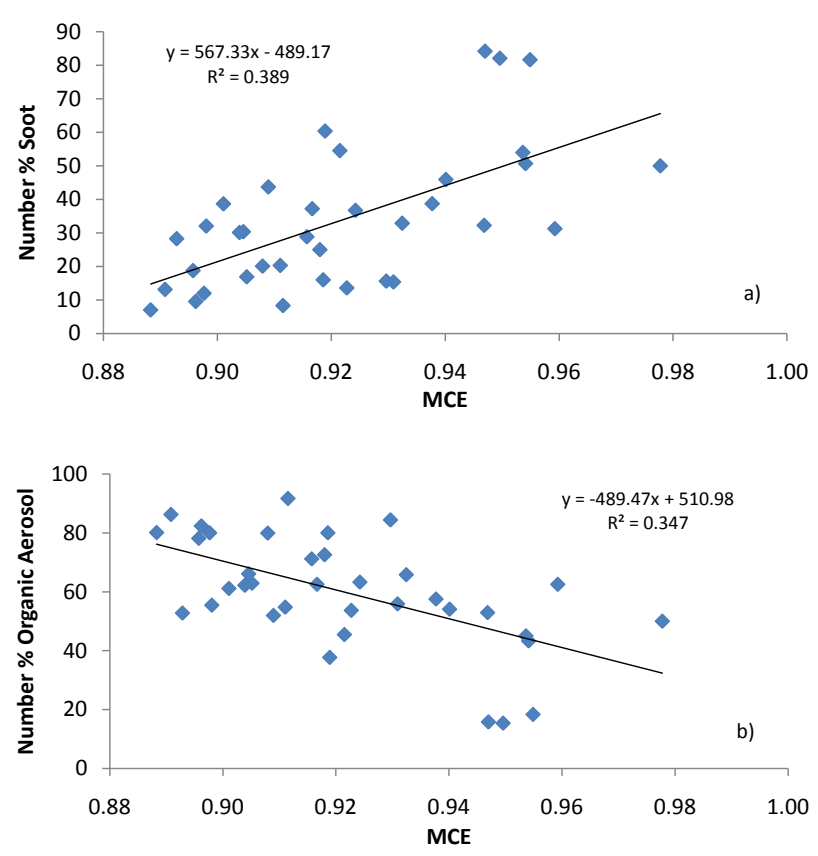

Fig. 6. The percentage of individual BB particles in a smoke sample that are classified as (a) soot or (b) organic aerosol plotted versus MCE. The tendency for flaming combustion to produce black carbon and smoldering combustion to produce organic aerosol is illustrated.

combustion of polyvinyl chloride and agricultural chemicals, respectively. Some particles are spherical (e.g., aggregated particles in the upper left of Fig. 7b), suggesting that they had been molten and cooled rapidly after emission. This process is similar to the production of coal fly ash; however, these particles could come from other combustion sources.

\subsection{The amount and distribution of open burning in Mexico derived from space-based active fire detection}

The Fire Inventory from NCAR version 1 (FINNv1) model calculates the global biomass consumption due to open burning based on active fire detection with daily temporal resolution and $1 \mathrm{~km}^{2}$ spatial resolution (Wiedinmyer et al., 2010). In Fig. 8 we show the 2006 total combusted biomass (estimated by FINNv1) for each Mexican state divided by the state area. A continuous arc with high rates of BB stretches across Mexico to the south of the MCMA for $\sim 2000 \mathrm{~km}$; from the Mexican states of Quintana Roo on the Yucatan peninsula in the east to Jalisco on the west coast. The MCMA itself is also a small active fire zone, potentially because the large population leads to a high rate of accidental fires (E. Alvarado, personal communication, 2009). In Table 8 we show the total biomass combusted in open fires in 2006 in Mexico partitioned into a vegetation classification corresponding to our EF in Tables 2, 3, 5, and 6. The three most important types of open vegetation burning in the FINNv1 estimate are tropical forest $(63.6 \mathrm{Tg})$, savannas $(17.0 \mathrm{Tg})$, and temperate forest $(12.8 \mathrm{Tg})$. We note that the crop residue fire estimate $(2.9 \mathrm{Tg})$ is the category most likely to be underestimated because the small size and short duration of crop residue fires often leads to a low detection efficiency (Hawbaker et al., 2008; Yokelson et al., 2009 and references therein).

For comparison, Table 8 also includes an estimate for the sum of industrial and domestic biofuel use from Table 7 of Christian et al. (2010) and a crude estimate for garbage burning. The biofuel use estimate of $68 \mathrm{Tg} \mathrm{yr}^{-1}$ is the largest annual fuel consumption for the categories considered here. It should be noted that the estimate assumes that growth rates in biofuel use measured in past decades have continued through to the present (Yevich and Logan, 2003). Our rough estimate of the total amount of GB in Mexico is made as follows. Assuming that $0.9 \mathrm{~kg}$ of garbage is produced per day per capita in Mexico, based on the lower limit for residents in Mexico City (Ojeda-Benitz et al., 2008), we first calculate that $36.9 \mathrm{Tg}$ of garbage is generated annually by Mexico's population of 112468855 (https://www.cia.gov/library/ publications/the-world-factbook/geos/mx.html). The total annual amount of garbage burned in Mexico depends on the percentage assumed to burn: a number which is not known. McCulloch et al. (1999) estimated that $50 \%$ of garbage generated globally was burned, but that percentage included garbage burned in modern incineration facilities in addition to open burning. Assuming a range from $10-50 \%$, the total amount of garbage burned in Mexico is $3.7-18.5 \mathrm{Tg} \mathrm{yr}^{-1}$. Garbage contains a lot of biomass, but also a lot of plastic and other material (Christian et al., 2010 and references therein). Together BB and GB are estimated to account for roughly $175 \mathrm{Tg}$ of fuel consumption in 2006 in Mexico and based on total hotspots, 2006 was a typical year for open burning in Mexico as shown in Supplement Fig. 1 (MODIS hotspots for 2003-2010 were obtained from the Mexican Comisión Nacional para el Conocimiento y Uso de la Biodiversidad (CONABIO) website at: http://www.conabio.gob.mx/ conocimiento/puntos_calor/doctos/puntos_calor.html, hereinafter cited as "CONABIO" or from FINNv1). There is high uncertainty in all the fuel consumption estimates and considerable variation between available estimates as discussed in detail by Wiedinmyer et al. (2010). For instance, if we use GFED3 (van der Werf et al., 2010) instead of FINNv1 to estimate the fuel consumption by open BB, the total fuel consumption by biomass burning plus garbage burning would go down by about $40 \%$. On the other hand, several recent studies suggest that many current emissions inventories underestimate the emissions from biomass burning in the tropics (e.g. Kopacz et al., 2010; Liu et al., 2011) or boreal regions (Yurganov et al., 2011), which implies that the amount of biomass burned may be underestimated. We discuss the impacts of the $\mathrm{BB}+\mathrm{GB}$ emissions further in Sect. 3.5, and it is clear that they are large enough to be of major importance regardless of the specific inventory used. 

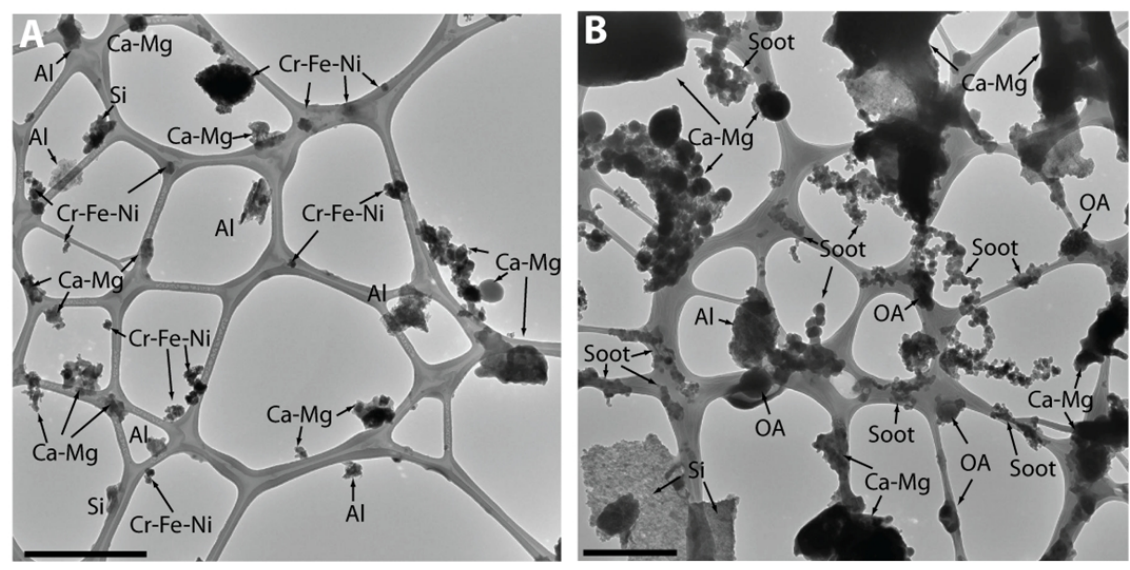

Fig. 7. TEM image of smoke samples from (a) garbage burning and (b) mixture of garbage burning and crop residue burning. The black horizontal bar at the base of each image indicates 1 micron. See Sect. 3.2 for discussion.

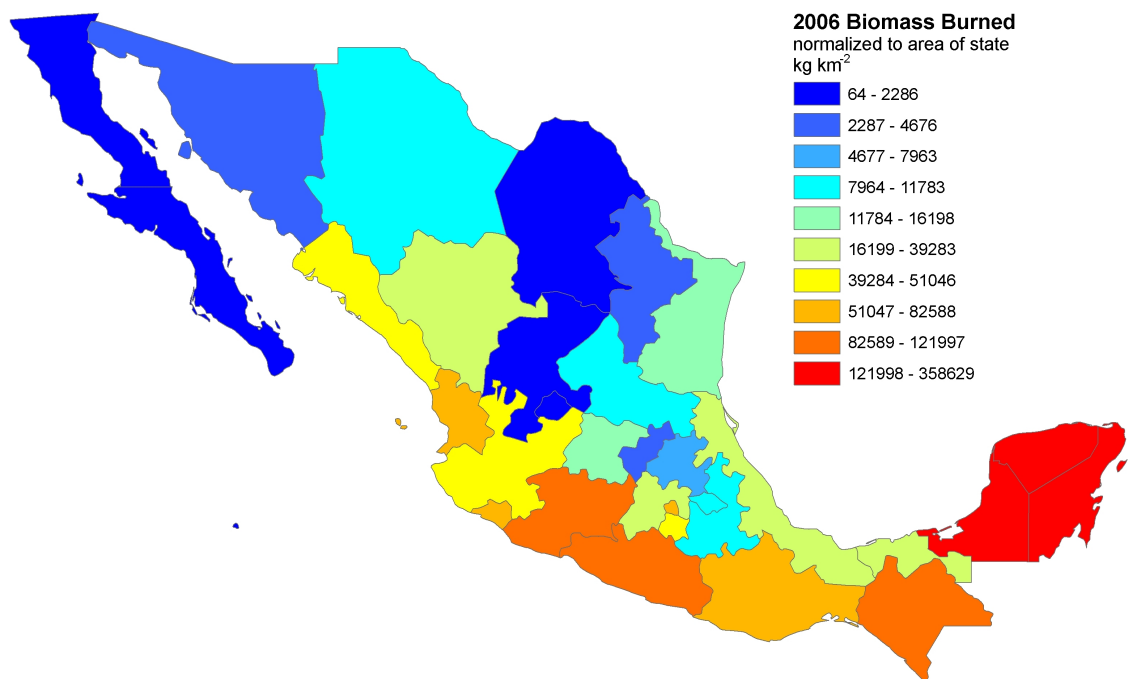

Fig. 8. Map showing the amount of biomass burned in each Mexican state (as calculated by the FINNv1 model) normalized by the area of the state. The warm colors indicate an arc of high intensity biomass burning south of the Mexico City metropolitan area and stretching about $2000 \mathrm{~km}$ from coast to coast.

\subsection{Airborne search for fires and regional transport of open burning emissions}

The distribution and amount of open burning is typically retrieved from space-based detection of burned area or hotspots (Wiedinmyer et al., 2006, 2010; Reid et al., 2009; Giglio et al., 2010; van der Werf et al., 2010) and an example of that approach (FINNv1) is described in the previous section. Given the inherent limitations of space-based sensors, it is of interest that our effort to locate fires for emissions sampling provides partially independent information on what burns in Mexico. We followed a simple strategy to locate fires for emissions sampling. If an area had MODIS hotspots (CONABIO) on a particular day and the forecast was for dry weather, it was classified as a location with high potential for fires for the next day's flight. We attempted to sample fires in all areas of south-central Mexico that had exhibited high numbers of hotspots since 2003 (CONABIO). We sampled fires in all such areas except the valley of the Usumacinta River along the border of Chiapas with the Yucatan peninsula. Significant hotspot occurrence in this area did not begin until April 2006.

Following the above strategy we located more than 60 fires during our airborne search and 56 of these fires were large enough that we could acquire high quality emissions data from the aircraft (Table 1). For each of those 56 fires we checked if the fire had registered as a hotspot in the MODIS active fire product (Justice et al., 2002; CONABIO). A fire was considered to have been detected if there was a hotspot within $2 \mathrm{~km}$ of its location from either the Terra or Aqua daytime overpasses. Thus, in some cases the hotspot match 
Table 8. Rough comparison of selected primary emissions from combustion in Mexico.

\begin{tabular}{lrrrrrrrrr}
\hline $\begin{array}{l}\text { Combustion } \\
\text { Type }\end{array}$ & $\begin{array}{r}\text { Tropical } \\
\text { Forest }\end{array}$ & Savanna & $\begin{array}{r}\text { Temperate } \\
\text { Forest }\end{array}$ & $\begin{array}{r}\text { Crop } \\
\text { Residue }\end{array}$ & Biofuel $^{1}$ & Garbage & $\begin{array}{r}\text { National } \\
\text { BB+GB }\end{array}$ & $\begin{array}{r}\text { National } \\
\text { Urban }^{1}\end{array}$ & $\begin{array}{r}\text { BB+GB/ } \\
\text { Urban }\end{array}$ \\
\hline Tg Burned & 63.6 & 17 & 12.8 & 2.9 & 68 & 11.1 & 175.4 & & \\
EFCO & 87.10 & 79.28 & 102.90 & 85.56 & 58.40 & 41.46 & - & - & - \\
$\mathrm{EFPM}_{2.5}$ & 4.91 & 7.65 & 11.33 & 6.26 & 6.73 & 10.48 & - & - & - \\
$\mathrm{EFNH}_{3}$ & 2.48 & 0.57 & 0.54 & 1.76 & 0.44 & 1.04 & - & - & - \\
$\mathrm{EFNMOC}^{2}$ & 11.94 & 15.90 & 15.16 & 13.92 & 4.64 & 8.11 & - & - & - \\
$\mathrm{EFNO}_{\mathrm{x}}$ & 4.63 & 6.09 & 3.66 & 3.64 & 2.04 & 4.48 & - & - & - \\
$\mathrm{Tg} \mathrm{CO}_{\mathrm{Tg} \mathrm{PM}}$ & 5.54 & 1.35 & 1.32 & 0.25 & 3.97 & 0.46 & 12.88 & 6.68 & 1.93 \\
$\mathrm{Tg} \mathrm{NH}_{3}$ & 0.31 & 0.13 & 0.15 & 0.018 & 0.46 & 0.12 & 1.18 & 0.025 & 47.18 \\
$\mathrm{Tg} \mathrm{NMOC}^{2}$ & 0.16 & 0.010 & 0.007 & 0.005 & 0.030 & 0.012 & 0.22 & 0.065 & 3.40 \\
$\mathrm{Tg} \mathrm{NO}_{\mathrm{x}}$ & 0.76 & 0.27 & 0.19 & 0.040 & 0.32 & 0.090 & 1.67 & 1.98 & 0.84 \\
\hline
\end{tabular}

${ }^{1} \mathrm{EFNO}_{\mathrm{x}}$ for biofuel Bertschi et al. (2003), all other biofuel EF Table 3 of Christian et al. (2010), urban emissions Table 7 Christian et al. (2010).

2 The emission factor for the sum of identified NMOC. EFNMOC and total NMOC emissions for BB and GB are much larger (see text).

could be due to a different fire at nearly the same location, but at a different time. The $2 \mathrm{~km}$ threshold was selected to account for the MODIS nadir spatial resolution $(1 \mathrm{~km})$, the MODIS point response function, and possible uncertainty due to evolution in the spatial distribution of the fire. Despite the fact that we used hotspots to guide our search for fires, only 10 of the 56 fires shown in Table 1 were detected as hotspots. Factors influencing the detection rate are discussed elsewhere (Yokelson et al., 2007a, 2009; Wiedinmyer et al., 2010). Comparison of Figs. 1 and 8 shows that there is good correlation between where we successfully located fires and where the FINNv1 model places the highest BB rates, but systematic measurement of the detection rate for various fire types would be valuable.

Taking the fires we located in the airborne search as one estimate of the distribution of Mexican BB, we explored the impacts of this open burning by running HYSPLIT 5-day forward trajectories (Draxler and Rolph, 2010) from all the open fires we sampled in 2006 and 2007. The starting altitudes were chosen to reflect the typically observed low injection altitudes (all within the boundary layer). Since biomass burning usually peaks in April and May in Mexico (CONABIO); for a few March 2006 fires we also ran forward trajectories starting at the same time of day, but during the months of April and May. The dispersion (not shown) was very similar. We limit the discussion here to potential air quality impacts on the Mexico City metropolitan area (MCMA) since it is Mexico's main population center. During a 2003 experiment focused on MCMA air quality, forward trajectories showed that fires in the Yucatan/Chiapas border region affected the MCMA (Molina et al., 2007). Our trajectories indicate that in 2006, pine-oak forest fires in the mountains adjacent to the MCMA and savanna fires along the Pacific Coast (SE of the MCMA) were more likely to impact the MCMA than emissions from Yucatan fires since the latter by- passed the MCMA. The importance of nearby fires and the low impact of Yucatan fires on the MCMA airshed during 2006 were confirmed using trajectories from other models reported elsewhere (Aiken et al., 2010; DeCarlo et al., 2010; de Foy et al., 2011). The difference in transport patterns between 2003 and 2006 could stem from the El Nino/Southern Oscillation (ENSO) phase: 2003 was an El Niño year while 2006 was ENSO-neutral. The trajectories for the Spring of 2006 could be closer to the long-term average (de Foy et al., 2008). In any case, there is an extensive BB zone to the south of the MCMA in both the FINNv1 results and our airborne fire search results. This suggests that many different regional transport patterns, with a northerly component, could potentially carry BB emissions to the MCMA.

\subsection{Summary of chemistry, climate, and air quality impacts of the different types of combustion in Mexico}

About $70-80 \%$ of open BB occurs in the tropics (van der Werf et al., 2010) along with large amounts of biofuel use and garbage burning (GB), both in rural and urban areas. In addition, the tropics contain an increasing number of megacities due to rapid population growth and urbanization. These emission sources are of critical interest because the tropics are also the key to the oxidizing power of the global atmosphere (Crutzen and Andreae, 2000). The publication of the MILAGRO 2006-2007 BB measurements and the long history of detailed studies of MCMA air quality (e.g. Raga et al., 2001; Molina et al., 2007) suggest that Mexico is very likely the tropical country that is best characterized from an emissions standpoint. Thus, it is of interest to gain insight into the atmospheric chemistry of the tropics by comparing the magnitude of the diverse combustion emission sources in Mexico as a model country for this globally important region. 
In Table 8, for the main types of open vegetation burning in Mexico, we coupled the FINNv1 national fuel consumption estimates with our field-measured EFs to estimate the total national emissions from these types of burning for several key species. We also show the national biofuel consumption and the national urban emissions taken from Table 7 of Christian et al. (2010). We coupled the national biofuel consumption with Mexican cooking fire EFs from Table 3 of Christian et al. (2010) and $\mathrm{NO}_{\mathrm{x}} \mathrm{EF}$ for cooking fires from Table 1 of Bertschi et al. (2003). The national urban emissions were derived by scaling the 2004 MCMA emissions inventory (http://www.sma.df.gob.mx/sma/index.php?opcion= $26 / \triangle$ id $=392)$ to the total urban population of Mexico $(\sim 75$ million), as described in detail by Christian et al. (2010).

The estimated ratio of the annual national primary emissions from BB plus GB to the annual national primary emissions from fossil fuel (FF) combustion in urban areas for some key atmospheric species follows: $\mathrm{CO}$ (1.9), $\mathrm{PM}_{2.5}$ (47), $\mathrm{NH}_{3}$ (3.4), NMOC (0.84), and $\mathrm{NO}_{\mathrm{x}}(0.96)$ (Table 8, last column rounded to two significant figures). In reality, these ratios are highly uncertain since all the underlying BB, GB, and FF estimates are uncertain by at least a factor of two. In addition, secondary aerosol formation is not considered. The evolution of the aerosol/CO ratio was measured in one Mexican BB plume and it more than doubled in a little over one hour (Yokelson et al., 2009). Ratios of secondary to primary aerosol close to a factor of ten have been observed for urban aerosol generated primarily by FF combustion in Mexico (e.g. Salcedo et al., 2006). We also note that the estimates of the EFs for total NMOC produced by BB and GB in Table 8 are at least a factor of 2 too low since they rely completely on species that could be quantified with FTIR and WAS. BB studies that also incorporated mass spectrometric sampling (e.g. Christian et al., 2003; Yokelson et al., 2008) typically yield EFNMOC closer to $30 \mathrm{~g} \mathrm{~kg}^{-1}$ for most types of BB, or about twice the largest EFNMOC shown for BB in Table 8. Further, the studies that include mass spectrometric techniques still only account for roughly half the mass of NMOC emitted by BB (Karl et al., 2007). In developed countries, urban emissions from burning FF dominate the total combustion emissions (Forster et al., 2007). FF emissions are also significant in developing countries, but from a tropical (and therefore global) atmospheric chemistry standpoint the emissions from both $\mathrm{BB}$ and $\mathrm{FF}$ are significant, with our observations confirming that $\mathrm{BB}$ is especially likely to dominate the aerosol emissions in the tropics. This is consistent with past estimates that $\mathrm{BB}$ produces about $60 \%$ of global BC and $94 \%$ of primary combustion-generated organic aerosol (Bond et al., 2004).

The climate impacts of BB are complex. Recently, increased attention has been focused on reducing one aerosol component, BC, as a means of achieving rapid, partial mitigation of global warming (Jacobson, 2002; Unger et al., 2010). However, airborne TEM and ground-based filter samples of BB aerosol during MILAGRO confirm that BB aerosol is mostly composed of OA. For instance, with the exception of brick kilns, the 2007 filter-based measurements of BB sources in Mexico found that the EC (a surrogate for BC) emissions were $\sim 12 \pm 12 \%$ of the co-emitted OA by mass (range 0.6-36\%, based on Table 4 of Christian et al., 2010). The dominant OA emissions contribute to short term cooling through a variety of direct and indirect effects (Reid et al., 2005) and even the net forcing of the $\mathrm{BC}$ is unclear when indirect effects are considered (Koch and Genio, 2010). BC can undergo long-range transport and increase snow/ice melt rates even when co-emitted with organic species (Hadley et al., 2010). However, BC produced by BB is more hygroscopic and shorter lived than BC produced by FF (Petters et al., 2009). While most of the greenhouse gases emitted by savanna fires are quickly taken up by regrowth of new grasses, deforestation fires are a net source of greenhouse gases (Forster et al., 2007). For these and other reasons, the climate impacts of BB in Mexico and globally will require much more research.

From an air quality perspective, the health impacts of FF emissions are likely magnified relative to most open burning emissions since the FF emissions are produced primarily in the major population centers. However, open GB also occurs in or near urban areas. GB is identified as the main global source of dioxins and likely produces numerous other air toxics (Costner, 2006). In addition, open BB emissions can be transported to major urban areas both in Mexico and globally (Moffet et al., 2008; Aiken et al., 2010; Yokelson et al., 2007b) and the health effects of biofuel use, which mainly consists of open cooking fires built within rural dwellings is a major global public health issue (Dherani et al., 2008).

\section{Conclusions}

During 2006 and 2007 the initial emissions from 78 fires were measured in Mexico from airborne platforms or a ground-based mobile lab. The fires sampled included examples of most types of open burning and several types of domestic and industrial biofuel use. In this paper we have used the emissions data to derive national-average emission factors (EF) for 6 types of open burning: savanna, tropical dry forest, crop residue, pine-oak (temperate forest), mixed crop residue and tropical dry forest, and garbage burning. The EF for early dry season savanna fires were found to be higher than the EF for late dry season savanna fires for $\mathrm{NO}_{\mathrm{x}}$ and many smoldering compounds. Comparison of the emissions from pine-oak forest fires in urban and rural areas of Mexico showed that $\mathrm{NO}_{\mathrm{x}}$ emissions were about a factor of two higher from the urban-impacted forests; perhaps as a result of nitrogen deposition. The emissions from fires that started as crop residue fires, but escaped to also burn some adjacent forest (possibly due to high surface windspeeds) were examined as a group. The fires that burned both fuel types emitted significantly more $\mathrm{NO}_{\mathrm{x}}$ than the fires that burned just one of the 
two component fuel types. Thus, for $\mathrm{NO}_{\mathrm{x}}$ and perhaps some other species, deposition, seasonal phenology, windspeed, or other factors, may play as large a role in controlling EF as vegetation type does.

Both TEM and filter-based techniques were used to analyze numerous samples of Mexican BB aerosol. Both approaches show the overall aerosol composition was dominated by organic species. On average, soot accounted for $\sim 27 \%$ of BB aerosol particles by number and EC accounted for $\sim 12 \%$ of $\mathrm{BB}$ aerosol by mass. When considering all the fires sampled from the air, the percentage of individual aerosol particles that were identified as soot by TEM was positively correlated with MCE. The percentage of organic aerosol particles was negatively correlated with MCE. These observations are consistent with findings that flaming combustion is the source of black carbon and that smoldering combustion produces most of the organic aerosol.

The FINNv1 model and an airborne search for fires both suggest that an arc of intense, March-May, open biomass burning stretches across southern Mexico to the south of Mexico City. Mexico City may be most frequently affected by open BB in the pine-oak forest found in the nearby mountains and savanna fires on the west coast. About $175 \mathrm{Tg} \mathrm{yr}^{-1}$ of biomass, biofuel, and garbage is burned in a typical year in Mexico and the emissions released to the atmosphere rival or exceed those from urban fossil fuel use for many species. This confirms the important role of biomass burning in the atmospheric chemistry of the global tropics.

\section{Supplementary material related to this article is available online at: http://www.atmos-chem-phys.net/11/6787/2011/ acp-11-6787-2011-supplement.pdf.}

Acknowledgements. The authors thank Eric Hintsa and AnneMarie Schmoltner of NSF for supplemental funding for ASU and $\mathrm{U}$ Miami, and NCAR for providing travel funds for CU to conduct measurements on the Twin Otter. We thank the Twin Otter pilots. Thanks go to Sasha Madronich, Luisa Molina, and Jose Meitin for coordinating the overall MILAGRO campaign. The University of Montana and the Twin Otter were supported mostly by NSF grants ATM-0513055 and ATM-0936321. Yokelson and Burling were also supported by the Strategic Environmental Research and Development Program (SERDP) of DoD. Support for the USFS and Twin Otter was provided by the NASA North American Carbon Plan (NNHO5AA86I). Participation by Arizona State University was supported by NSF grant ATM-0531926. We gratefully acknowledge the use of TEMs within the LeRoy Eyring Center for Solid State Science at Arizona State University. Support to the University of Miami was provided by NSF (ATM 0511820). X. Zhu and L. Pope provided excellent technical support for the canister trace gas analyses. We thank Holly Eissinger for production of Fig. 1 and Supplement Fig. 1.

Edited by: M. Gauss

\section{References}

Adachi, K. and Buseck, P. R.: Internally mixed soot, sulfates, and organic matter in aerosol particles from Mexico City, Atmos. Chem. Phys., 8, 6469-6481, doi:10.5194/acp-8-6469-2008, 2008.

Adachi, K. and Buseck, P. R.: Hosted and free-floating metalbearing atmospheric nanoparticles in Mexico City, Environ. Sci. Technol., 44, 2299-2304, 2010.

Adachi, K. and Buseck, P. R.: Atmospheric tar balls from biomass burning in Mexico, J. Geophys. Res., 116, D05204, doi:10.1029/2010JD015102, 2011.

Adachi, K., Chung, S. H., and Buseck, P. R.: Shapes of soot aerosol particles and implications for their effects on climate, J. Geophys. Res., 115, D15206, doi:10.1029/2009JD012868, 2010.

Aiken, A. C., de Foy, B., Wiedinmyer, C., DeCarlo, P. F., Ulbrich, I. M., Wehrli, M. N., Szidat, S., Prevot, A. S. H., Noda, J., Wacker, L., Volkamer, R., Fortner, E., Wang, J., Laskin, A., Shutthanandan, V., Zheng, J., Zhang, R., Paredes-Miranda, G., Arnott, W. P., Molina, L. T., Sosa, G., Querol, X., and Jimenez, J. L.: Mexico city aerosol analysis during MILAGRO using high resolution aerosol mass spectrometry at the urban supersite (T0) - Part 2: Analysis of the biomass burning contribution and the non-fossil carbon fraction, Atmos. Chem. Phys., 10, 5315-5341, doi:10.5194/acp-10-5315-2010, 2010.

Akagi, S. K., Yokelson, R. J., Wiedinmyer, C., Alvarado, M. J., Reid, J. S., Karl, T., Crounse, J. D., and Wennberg, P. O.: Emission factors for open and domestic biomass burning for use in atmospheric models, Atmos. Chem. Phys., 11, 4039-4072, doi:10.5194/acp-11-4039-2011, 2011.

Alvarado, M. J. and Prinn, R. G.: Formation of ozone and growth of aerosols in young smoke plumes from biomass burning: 1. Lagrangian parcel studies, J. Geophys. Res., 114, D09306, doi:10.1029/2008JD011144, 2009.

Andreae, M. O. and Merlet, P.: Emission of trace gases and aerosols from biomass burning, Global Biogeochem. Cy., 15(4), 955-966, doi:10.1029/2000GB001382, 2001.

Bertschi, I. T., Yokelson, R. J., Ward, D. E., Christian, T. J., and Hao, W. M.: Trace gas emissions from the production and use of domestic biofuels in Zambia measured by open-path Fourier transform infrared spectroscopy, J. Geophys. Res., 108(D13), 8469, doi:10.1029/2002JD002158, 2003.

Bond, T. C. and Bergstrom, R. W.: Light absorption by carbonaceous particles: An investigative review, Aerosol Sci. Technol., 40, 27-67, 2006.

Bond, T. C., Streets, D. G., Yarber, K. F., Nelson, S. M., Woo, J.H., and Klimont, Z.: A technology-based global inventory of black and organic carbon emissions from combustion, J. Geophys. Res., 109, D14203, doi:10.1029/2003JD003697, 2004.

Burling, I. R., Yokelson, R. J., Griffith, D. W. T., Johnson, T. J., Veres, P., Roberts, J. M., Warneke, C., Urbanski, S. P., Reardon, J., Weise, D. R., Hao, W. M., and de Gouw, J.: Laboratory measurements of trace gas emissions from biomass burning of fuel types from the southeastern and southwestern United States, Atmos. Chem. Phys., 10, 11115-11130, doi:10.5194/acp10-11115-2010, 2010.

Christian, T. J., Kleiss, B., Yokelson, R. J., Holzinger, R., Crutzen, P. J., Hao, W. M., Saharjo, B. H., and Ward, D. E.: Comprehensive laboratory measurements of biomass-burning emissions: 1 . Emissions from Indonesian, African, and other fuels, J. Geophys. 
Res., 108(D23), 4719, doi:10.1029/2003JD003704, 2003.

Christian, T. J., Yokelson, R. J., Crdenas, B., Molina, L. T., Engling, G., and Hsu, S.-C.: Trace gas and particle emissions from domestic and industrial biofuel use and garbage burning in central Mexico, Atmos. Chem. Phys., 10, 565-584, doi:10.5194/acp-10565-2010, 2010.

Chung, S. H. and Seinfeld, J. H.: Global distribution and climate forcing of carbonaceous aerosols, J. Geophys. Res., 107(D19), 4407, doi:10.1029/2001JD001397, 2002.

Costner, P.: Update of Dioxin Emission Factors for Forest Fires, Grassland and Moor Fires, Open Burning of Agricultural Residues, Open Burning of Domestic Waste, Landfills and Dump Fires, International POPs Elimination Network, Mexico, 13 pp., 2006.

Crounse, J. D., DeCarlo, P. F., Blake, D. R., Emmons, L. K., Campos, T. L., Apel, E. C., Clarke, A. D., Weinheimer, A. J., McCabe, D. C., Yokelson, R. J., Jimenez, J. L., and Wennberg, P. O.: Biomass burning and urban air pollution over the Central Mexican Plateau, Atmos. Chem. Phys., 9, 4929-4944, doi:10.5194/acp-9-4929-2009, 2009.

Crutzen, P. J. and Andreae, M. O.: Biomass burning in the tropics: Impact on atmospheric chemistry and biogeochemical cycles, Science, 250, 1669-1678, 1990.

DeCarlo, P. F., Ulbrich, I. M., Crounse, J., de Foy, B., Dunlea, E. J., Aiken, A. C., Knapp, D., Weinheimer, A. J., Campos, T., Wennberg, P. O., and Jimenez, J. L.: Investigation of the sources and processing of organic aerosol over the Central Mexican Plateau from aircraft measurements during MILAGRO, Atmos. Chem. Phys., 10, 5257-5280, doi:10.5194/acp-10-52572010, 2010.

de Foy, B., Fast, J. D., Paech, S. J., Phillips, D., Walters, J. T., Coulter, R. L., Martin, T. J., Pekour, M. S., Shaw, W. J., Kastendeuch, P. P., Marley, N. A., Retama, A., and Molina, L. T.: Basinscale wind transport during the MILAGRO field campaign and comparison to climatology using cluster analysis, Atmos. Chem. Phys., 8, 1209-1224, doi:10.5194/acp-8-1209-2008, 2008.

de Foy, B., Burton, S. P., Ferrare, R. A., Hostetler, C. A., Hair, J. W., Wiedinmyer, C., and Molina, L. T.: Aerosol plume transport and transformation in high spectral resolution lidar measurements and WRF-Flexpart simulations during the MILAGRO Field Campaign, Atmos. Chem. Phys., 11, 3543-3563, doi:10.5194/acp-11-3543-2011, 2011

de Gouw, J. and Jimenez, J. L.: Organic aerosols in the Earth's atmosphere, Environ. Sci. Technol., 43, 7614-7618, doi:10.1021/Es9006004, 2009.

Dherani, M., Pope, D., Mascarenhas, M., Smith, K. R., Weber, M., and Bruce, N.: Indoor air pollution from unprocessed solid fuel use and pneumonia risk in children aged under five years: a systematic review and meta-analysis, Bull. World Health Organ. 86(5), 390-398, 2008.

Draxler, R. R. and Rolph, G. D.: HYSPLIT (HYbrid Single-Particle Lagrangian Integrated Trajectory) Model access via NOAA ARL READY Website (http://ready.arl.noaa.gov/HYSPLIT. php), NOAA Air Resources Laboratory, Silver Spring, MD., 2010.

Fast, J. D., de Foy, B., Acevedo Rosas, F., Caetano, E., Carmichael, G., Emmons, L., McKenna, D., Mena, M., Skamarock, W., Tie, X., Coulter, R. L., Barnard, J. C., Wiedinmyer, C., and Madronich, S.: A meteorological overview of the MILA-
GRO field campaigns, Atmos. Chem. Phys., 7, 2233-2257, doi:10.5194/acp-7-2233-2007, 2007.

Ferek, R. J., Reid, J. S., Hobbs, P. V., Blake, D. R., and Liousse, C.: Emission factors of hydrocarbons, halocarbons, trace gases, and particles from biomass burning in Brazil, J. Geophys. Res., 103(D24), 32107-32118, doi:10.1029/98JD00692, 1998.

Flocke, F., Herman, R. L., Salawitch, R. J., Atlas, E., Webster, C. R., Schauffler, S. M., Lueb, R. A., May, R. D., Moyer, E. J., Rosenlof, K. H., Scott, D. C., Blake, D. R., and Bui, T. P.: An examination of the chemistry and transport processes in the tropical lower stratosphere using observations of long-lived and short-lived compounds obtained during STRAT and POLARIS, J. Geophys. Res., 104, 26625-26642, 1999.

Forster, P., Ramaswamy, V., Artaxo, P., Berntsen, T., Betts, R., Fahey, D.W., Haywood, J., Lean, J., Lowe, D.C., Myhre, G., Nganga, J., Prinn, R., Raga, G., Schulz M., and Van Dorland, R.: Changes in Atmospheric Constituents and in Radiative Forcing, in: Climate Change 2007: The Physical Science Basis, contribution of Working Group I to the Fourth Assessment Report of the Intergovernmental Panel on Climate Change, edited by: Solomon, S. D., Qin, M., Manning, Z., Chen, M., Marquis, K. B., Averyt, M. T., and Miller, H. L., Cambridge University Press, Cambridge, United Kingdom and New York, NY, USA, 129134, 2007.

Giglio, L., Randerson, J. T., van der Werf, G. R., Kasibhatla, P. S., Collatz, G. J., Morton, D. C., and DeFries, R. S.: Assessing variability and long-term trends in burned area by merging multiple satellite fire products, Biogeosciences, 7, 1171-1186, doi:10.5194/bg-7-1171-2010, 2010.

Gong, S., Barrie, L., Prospero, J., Savoie, D., Ayers, G., Blanchet, J.-P., and Spacek, L.: Modeling sea-salt aerosols in the atmosphere 2. Atmospheric concentrations and fluxes, J. Geophys. Res., 102(D3), 3819-3830, 1997.

Goode, J. G., Yokelson, R. J., Ward, D. E., Susott, R. A., Babbitt, R. E., Davies, M. A., and Hao, W. M.: Measurements of excess $\mathrm{O}_{3}, \mathrm{CO}_{2}, \mathrm{CO}, \mathrm{CH}_{4}, \mathrm{C}_{2} \mathrm{H}_{4}, \mathrm{C}_{2} \mathrm{H}_{2}, \mathrm{HCN}, \mathrm{NO}, \mathrm{NH}_{3}$, $\mathrm{HCOOH}, \mathrm{CH}_{3} \mathrm{COOH}, \mathrm{HCHO}$, and $\mathrm{CH}_{3} \mathrm{OH}$ in 1997 Alaskan biomass burning plumes by airborne Fourier transform infrared spectroscopy (AFTIR), J. Geophys. Res., 105(D17), 22147 22166, doi:10.1029/2000JD900287, 2000.

Grieshop, A. P., Logue, J. M., Donahue, N. M., and Robinson, A. L.: Laboratory investigation of photochemical oxidation of organic aerosol from wood fires 1: measurement and simulation of organic aerosol evolution, Atmos. Chem. Phys., 9, 1263-1277, doi:10.5194/acp-9-1263-2009, 2009.

Hadley, O. L., Corrigan, C. E., Kirchstetter, T. W., Cliff, S. S., and Ramanathan, V.: Measured black carbon deposition on the Sierra Nevada snow pack and implication for snow pack retreat, Atmos. Chem. Phys., 10, 7505-7513, doi:10.5194/acp-10-75052010, 2010.

Hao, W. M., Ward, D. E., Olbu, G., and Baker, S. P.: Emissions of $\mathrm{CO}_{2}, \mathrm{CO}$, and hydrocarbons from fires in diverse African savanna ecosystems, J. Geophys. Res., 101, 23577-23584, 1996.

Hawbaker, T. J., Radeloff, V. C., Syphard, A. D. Zhu, Z., and Stewart, S. I.: Detection rates of the MODIS active fire product in the United States, Remote Sens. Environ., 112(5), 2656-2664, 2008.

Hoffa, E. A., Ward, D. E., Hao, W. M., Susott, R. A., and Wakimoto, R. H.: Seasonality of carbon emissions from biomass burning in a Zambian savanna, J. Geophys. Res., 104(D11), 13841-13853, 
1999.

Hughes, R. F., Kauffman, J. B., and Jaramillo, V. J.: Ecosystemscale impacts of deforestation and land use in a humid tropical region of Mexico, Ecol. Appl., 10(2), 515-527, 2000.

Jacobson, M. Z.: Strong radiative heating due to the mixing state of black carbon in atmospheric aerosols, Nature, 409, 695-697, 2001.

Jacobson, M. Z.: Control of fossil-fuel particulate black carbon and organic matter, possibly the most effective method of slowing global warming, J. Geophys. Res., 107(D19), 4410, doi:10.1029/2001JD001376, 2002.

Jaramillo, V. J., Kauffman, J. B., Rentería-Rodríguez, L., Cummings, D. L., and Ellingson, L. J.: Biomass, carbon, and nitrogen pools in Mexican tropical dry forest landscapes, Ecosystems, 6, 609-629, 2003.

Justice, C. O., Giglio, L., Korontzi, S., Owens, J., Morisette, J. T., Roy, D., Descloitres, J., Alleaume, S., Petitcolin, F., and Kaufman, Y.: The MODIS fire products, Remote Sens. Environ., 83, 244-262, 2002.

Karl, T. G., Christian, T. J., Yokelson, R. J., Artaxo, P., Hao, W. M., and Guenther, A.: The Tropical Forest and Fire Emissions Experiment: method evaluation of volatile organic compound emissions measured by PTR-MS, FTIR, and GC from tropical biomass burning, Atmos. Chem. Phys., 7, 5883-5897, doi:10.5194/acp-7-5883-2007, 2007.

Kennedy, I. M.: Models of soot formation and oxidation, Prog. Energy Combust. Sci., 23, 95-132, 1997.

Koch, D. and Del Genio, A. D.: Black carbon semi-direct effects on cloud cover: review and synthesis, Atmos. Chem. Phys., 10, 7685-7696, doi:10.5194/acp-10-7685-2010, 2010.

Kopacz, M., Jacob, D. J., Fisher, J. A., Logan, J. A., Zhang, L., Megretskaia, I. A., Yantosca, R. M., Singh, K., Henze, D. K., Burrows, J. P., Buchwitz, M., Khlystova, I., McMillan, W. W., Gille, J. C., Edwards, D. P., Eldering, A., Thouret, V., and Nedelec, P.: Global estimates of CO sources with high resolution by adjoint inversion of multiple satellite datasets (MOPITT, AIRS, SCIAMACHY, TES), Atmos. Chem. Phys., 10, 855-876, doi:10.5194/acp-10-855-2010, 2010.

Korontzi, S., Ward, D. E., Susott, R. A., Yokelson, R. J., Justice, C. O., Hobbs, P. V., Smithwick, E. A. H., and Hao, W. M.: Seasonal variation and ecosystem dependence of emission factors for selected trace gases and $\mathrm{PM}_{2.5}$ for southern African savanna fires, J. Geophys. Res., 108, 4758, doi:10.1029/2003JD003730, 2003.

Lemieux, P. M., Lutes, C. C., Abbott, J. A., and Aldous, K. M.: Emissions of polychlorinated dibenzo-p-dioxins and polychlorinated dibenzofurans from the open burning of household waste in barrels, Environ. Sci. Technol., 34, 377-384, 2000.

Liu, C., Beirle, S., Butler, T., Liu, J., Hoor, P., Jöckel, P., Pozzer, A., Frankenberg, C., Lawrence, M. G., Lelieveld, J., Platt, U., and Wagner, T.: Application of SCIAMACHY and MOPITT CO total column measurements to evaluate model results over biomass burning regions and Eastern China, Atmos. Chem. Phys., 11, 6083-6114, doi:10.5194/acp-11-6083-2011, 2011.

McCulloch, A., Aucott, M. L., Benkovitz, C. M., Graede, T. E., Kleiman, G., Midgley, P. M., and Li, Y. F.: Global emissions of hydrogen chloride and chloromethane from coal combustion, incineration and industrial activities: Reactive Chlorine Emissions Inventory, J. Geophys. Res., 104(D7), 8391-8403, 1999.
McMeeking, G. R., Kreidenweis, S. M., Baker, S., Carrico, C. M., Chow, J. C., Collet Jr., J. L., Hao, W. M., Holden, A. S., Kirchstetter, T. W., Malm, W. C., Moosmüller, H., Sullivan, A. P., and Wold, C. E.: Emissions of trace gases and aerosols during the open combustion of biomass in the laboratory, J. Geophys. Res., 114, D19210, doi:10.1029/2009JD011836, 2009.

Moffet, R. C., de Foy, B., Molina, L. T., Molina, M. J., and Prather, K. A.: Measurement of ambient aerosols in northern Mexico City by single particle mass spectrometry, Atmos. Chem. Phys., 8 , 4499-4516, doi:10.5194/acp-8-4499-2008, 2008.

Molina, L. T., Kolb, C. E., de Foy, B., Lamb, B. K., Brune, W. H., Jimenez, J. L., Ramos-Villegas, R., Sarmiento, J., ParamoFigueroa, V. H., Cardenas, B., Gutierrez-Avedoy, V., and Molina, M. J.: Air quality in North America's most populous city overview of the MCMA-2003 campaign, Atmos. Chem. Phys., 7, 2447-2473, doi:10.5194/acp-7-2447-2007, 2007.

Molina, L. T., Madronich, S., Gaffney, J. S., Apel, E., de Foy, B., Fast, J., Ferrare, R., Herndon, S., Jimenez, J. L., Lamb, B., Osornio-Vargas, A. R., Russell, P., Schauer, J. J., Stevens, P. S., Volkamer, R., and Zavala, M.: An overview of the MILAGRO 2006 Campaign: Mexico City emissions and their transport and transformation, Atmos. Chem. Phys., 10, 8697-8760, doi:10.5194/acp-10-8697-2010, 2010.

Moteki, N. and Kondo, Y.: Effects of mixing state of black carbon measurements by laser-induced incandescence, Aerosol Sci. Tech., 41(4), 398-417, 2007.

Nance, J. D., Hobbs, P. V., Radke, L. F., and Ward, D. E.: Airborne measurements of gases and particles from an Alaskan wildfire, J. Geophys. Res., 98, 14873-14882, 1993.

Ojeda-Benitez, S., Armijo-de Vegab, C., and Marquez-Montenegro, M. Y.: Household solid waste characterization by family socioeconomic profile as unit of analysis, Resources, Conservation and Recycling, 52, 992-999, 2008.

Petters, M. D., Carrico, C. M., Kreidenweis, S. M., Prenni, A. J., DeMott, P. J., Collett, J. L., and Moosmüller, H.: Cloud condensation nucleation activity of biomass burning aerosol, J. Geophys. Res., 114, D22205, doi:10.1029/2009jd012353, 2009.

Raga, G. B., Baumgardner, D., Castro, T., Martínez-Arroyo A., and Navarro-González, R.: Mexico City air quality: A qualitative review of gas and aerosol measurements (1960-2000), Atmos. Environ., 35, 4041-4058, 2001.

Reid, J. S., Hobbs, P. V., Ferek, R. J., Martins, J. V., Blake, D. R., Dunlap, M. R., and Liousse, C.: Physical, chemical, and radiative characteristics of the smoke dominated regional hazes over Brazil, J. Geophys. Res., 103, 32059-32080, 1998.

Reid, J. S., Eck, T. F., Christopher, S. A., Koppmann, R., Dubovik, O., Eleuterio, D. P., Holben, B. N., Reid, E. A., and Zhang, J.: A review of biomass burning emissions part III: intensive optical properties of biomass burning particles, Atmos. Chem. Phys., 5, 827-849, doi:10.5194/acp-5-827-2005, 2005.

Reid, J. S., Hyer, E. J., Prins, E. M., Westphal, D. L., Zhang, J., Wang, J., Christopher, S. A., Curtis, C. A., Schmidt, C. C., Eleuterio, D. P., Richardson, K. A., and Hoffman, J. P.: Global monitoring and forecasting of biomass-burning smoke: Description and lessons from the Fire Locating and Modeling of Burning Emissions (FLAMBE) program, J. of Sel. Topics in Appl. Earth Obs. and Rem. Sens., 2, 144-162, 2009. 
Rothman, L. S., Gordon, I. E., Barbe, A., Benner, D. C., Bernath, P. F., Birk, M., Boudon, V., Brown, L. R., Campargue, A., Champion, J. P., Chance, K., Coudert, L. H., Dana, V., Devi, V. M., Fally, S., Flaud, J. M., Gamache, R. R., Goldman, A., Jacquemart, D., Kleiner, I., Lacome, N., Lafferty, W. J., Mandin, J. Y., Massie, S. T., Mikhailenko, S. N., Miller, C. E., Moazzen-Ahmadi, N., Naumenko, O. V., Nikitin, A. V., Orphal, J., Perevalov, V. I., Perrin, A., Predoi-Cross, A., Rinsland, C. P., Rotger, M., Simecková, M., Smith, M. A. H., Sung, K., Tashkun, S. A., Tennyson, J., Toth, R. A., Vandaele, A. C., and Vander Auwera, J.: The HITRAN 2008 molecular spectroscopic database, J. Quant. Spectrosc. Ra., 110, 533-572, 2009.

Salcedo, D., Onasch, T. B., Dzepina, K., Canagaratna, M. R., Zhang, Q., Huffman, J. A., DeCarlo, P. F., Jayne, J. T., Mortimer, P., Worsnop, D. R., Kolb, C. E., Johnson, K. S., Zuberi, B., Marr, L. C., Volkamer, R., Molina, L. T., Molina, M. J., Cardenas, B., Bernabé, R. M., Márquez, C., Gaffney, J. S., Marley, N. A., Laskin, A., Shutthanandan, V., Xie, Y., Brune, W., Lesher, R., Shirley, T., and Jimenez, J. L.: Characterization of ambient aerosols in Mexico City during the MCMA-2003 campaign with Aerosol Mass Spectrometry: results from the CENICA Supersite, Atmos. Chem. Phys., 6, 925-946, doi:10.5194/acp-6-9252006, 2006.

Shaddix, C. R., Harrington, J. E., and Smyth, K. C.: Quantitative measurements of enhanced soot production in a flickering methane/air diffusion flame, Combustion and Flame, 99, 723732, 1994

Sinha, P., Hobbs, P. V., Yokelson, R. J., Bertschi, I. T., Blake, D. R., Simpson, I. J., Gao, S., Kirchstetter, T. W., and Novakov, T.: Emissions of trace gases and particles from savanna fires in southern Africa, J. Geophys. Res., 108, 8487, doi:10.1029/2002JD002325, 2003.

Susott, R. A., Olbu, G. J., Baker, S. P., Ward, D. E., Kauffman, J. B., and Shea, R.: Carbon, hydrogen, nitrogen, and thermogravimetric analysis of tropical ecosystem biomass, in Biomass Burning and Global Change, edited by: J. S. Levine, 350-360, MIT Press, Cambridge, 1996.

Trent, A., Davies, M. A., Fisher, R., Thistle, H., and Babbitt, R.: Evaluation of optical instruments for real-time, continuous monitoring of smoke particulates, Tech. Rep. 00252860 MTDC, USDA Forest Service, Missoula Technology and Development Center, Missoula, Mont., 38 pp., 2000.

Trentmann, J., Yokelson, R. J., Hobbs, P. V., Winterrath, T., Christian, T. J., Andreae, M. O., and Mason, S. A.: An analysis of the chemical processes in the smoke plume from a savanna fire, J. Geophys. Res., 110, D12301, doi:10.1029/2004JD005628, 2005.

Unger, N., Bond, T. C., Wang, J. S., Koch, D. M., Menon, S. E., Shindell, D. T., and Bauer, S. E.: Attribution of climate forcing to economic sectors, P. Natl. Acad. Sci., 107, 3382-3387, doi:10.1073/pnas.0906548107, 2010.

USEPA: Compilation of air pollutant emission factors Volume I: Stationary point and area sources, AP-42, Office of Air Quality Planning and Standards, Office of Air and Radiation, Research Triangle Park, NC, 26 pp., 1995.

van der Werf, G. R., Randerson, J. T., Giglio, L., Collatz, G. J., Mu, M., Kasibhatla, P. S., Morton, D. C., DeFries, R. S., Jin, Y., and van Leeuwen, T. T.: Global fire emissions and the contribution of deforestation, savanna, forest, agricultural, and peat fires (19972009), Atmos. Chem. Phys., 10, 11707-11735, doi:10.5194/acp-
10-11707-2010, 2010.

Weinheimer, A. J., Montzka, D. D., Campos, T. L., Walega, J. G., Ridley, B. A., Donnelly, S. G., Keim, E. R., Del Negro, L. A., Proffitt, M. H., Margitan, J. J., Boering, K. A., Andrews, A E., Daube, B. C., Wofsy, S. C., Anderson, B. E., Collins, J. E., Sachse, G. W., Vay, S. A., Elkins, J. W., Wamsley, P. R., Atlas, E. L., Flocke, F., Schauffler, S., Webster, C. R., May, R. D., Loewenstein, M., Podolske, J. R., Bui, T. P., Chan, K. R., Bowen, S. W., Schoeberl, M. R., Lait, L. R., and Newman, P. A.: Comparison of DC-8 and ER-2 species measurements on 8 February 1996: $\mathrm{NO}, \mathrm{NO}_{\mathrm{y}}, \mathrm{O}_{3}, \mathrm{CO}_{2}, \mathrm{CH}_{4}$, and $\mathrm{N}_{2} \mathrm{O}$, J. Geophys. Res., 103, 22087-22096, 1998.

Wiedinmyer, C., Quayle, B., Geron, C., Belote, A., McKenzie, D., Zhang, X., O’Neill, S., and Wynne, K. K.: Estimating emissions from fires in North America for air quality modeling, Atmos. Environ., 40, 3419-3432, 2006.

Wiedinmyer, C., Akagi, S. K., Yokelson, R. J., Emmons, L. K., AlSaadi, J. A., Orlando, J. J., and Soja, A. J.: The Fire INventory from NCAR (FINN) a high resolution global model to estimate the emissions from open burning, Geosci. Model Dev. Discuss., 3, 2439-2476, doi:10.5194/gmdd-3-2439-2010, 2010.

Yevich, R. and Logan, J. A.: An assessment of biofuel use and burning of agricultural waste in the developing world, Global Biogeochem. Cy., 17(4), 1095, doi:10.1029/2002GB001952, 2003.

Yokelson, R. J., Ward, D. E., Susott, R. A., Reardon, J., and Griffith, D. W. T.: Emissions from smoldering combustion of biomass measured by open-path Fourier transform infrared spectroscopy, J. Geophys. Res., 102(D15), 18865-18877, 1997.

Yokelson, R. J., Goode, J. G., Ward, D. E., Susott, R. A., Babbitt, R. E., Wade, D. D., Bertschi, I., Griffith, D. W. T., and Hao, W. M.: Emissions of formaldehyde, acetic acid, methanol, and other trace gases from biomass fires in North Carolina measured by airborne Fourier transform infrared spectroscopy, J. Geophys. Res., 104(D23), 30109-30126, doi:10.1029/1999JD900817, 1999.

Yokelson, R. J., Bertschi, I. T., Christian, T. J., Hobbs, P. V., Ward, D. E., and Hao, W. M.: Trace gas measurements in nascent, aged, and cloud-processed smoke from African savanna fires by airborne Fourier transform infrared spectroscopy (AFTIR), J. Geophys. Res., 108(D13), 8478, doi:10.1029/2002JD002322, 2003.

Yokelson, R. J., Urbanski, S. P., Atlas, E. L., Toohey, D. W., Alvarado, E. C., Crounse, J. D., Wennberg, P. O., Fisher, M. E., Wold, C. E., Campos, T. L., Adachi, K., Buseck, P. R., and Hao, W. M.: Emissions from forest fires near Mexico City, Atmos. Chem. Phys., 7, 5569-5584, doi:10.5194/acp-7-5569-2007, 2007a.

Yokelson, R. J., Karl, T., Artaxo, P., Blake, D. R., Christian, T. J., Griffith, D. W. T., Guenther, A., and Hao, W. M.: The Tropical Forest and Fire Emissions Experiment: overview and airborne fire emission factor measurements, Atmos. Chem. Phys., 7, 5175-5196, doi:10.5194/acp-7-5175-2007, $2007 \mathrm{~b}$.

Yokelson, R. J., Christian, T. J., Karl, T. G., and Guenther, A.: The tropical forest and fire emissions experiment: laboratory fire measurements and synthesis of campaign data, Atmos. Chem. Phys., 8, 3509-3527, doi:10.5194/acp-8-3509-2008, 2008.

Yokelson, R. J., Crounse, J. D., DeCarlo, P. F., Karl, T., Urbanski, S., Atlas, E., Campos, T., Shinozuka, Y., Kapustin, V., Clarke, A. D., Weinheimer, A., Knapp, D. J., Montzka, D. D., Holloway, J., Weibring, P., Flocke, F., Zheng, W., Toohey, D., Wennberg, P. O., Wiedinmyer, C., Mauldin, L., Fried, A., Richter, D., Walega, 
J., Jimenez, J. L., Adachi, K., Buseck, P. R., Hall, S. R., and Shetter, R.: Emissions from biomass burning in the Yucatan, Atmos. Chem. Phys., 9, 5785-5812, doi:10.5194/acp-9-5785-2009, 2009.
Yurganov, L., Rakitin, V., Dzhola, A., August, T., Fokeeva, E., Gorchakov, G., Grechko, E., Hannon, S., Karpov, A., Ott, L., Semutnikova, E., Shumsky, R., and Strow, L.: Satellite- and ground-based CO total column observations over 2010 Russian fires: accuracy of top-down estimates based on thermal IR satellite data., Atmos. Chem. Phys. Discuss., 11, 12207-12250, doi:10.5194/acpd-11-12207-2011, 2011. 